\title{
The ESCOMPTE Program: an overview
}

B. Cros, P. Durand, H. Cachier, P. Drobinski, E. Fréjafon, C. Kottmeier, P.-E. Perros, V.-H. Pech, J.-L. Ponche, D. Robin, et al.

\section{To cite this version:}

B. Cros, P. Durand, H. Cachier, P. Drobinski, E. Fréjafon, et al.. The ESCOMPTE

Program: an overview. Atmospheric Research, Elsevier, 2004, 69 (3-4), pp.241-279. 10.1016/j.atmosres.2003.05.001 . hal-00136317

\section{HAL Id: hal-00136317 \\ https://hal.archives-ouvertes.fr/hal-00136317}

Submitted on 2 Mar 2021

HAL is a multi-disciplinary open access archive for the deposit and dissemination of scientific research documents, whether they are published or not. The documents may come from teaching and research institutions in France or abroad, or from public or private research centers.
L'archive ouverte pluridisciplinaire HAL, est destinée au dépôt et à la diffusion de documents scientifiques de niveau recherche, publiés ou non, émanant des établissements d'enseignement et de recherche français ou étrangers, des laboratoires publics ou privés. 


\title{
The ESCOMPTE program: an overview
}

\author{
B. $\operatorname{Cros}^{\mathrm{a}, *}$, P. Durand ${ }^{\mathrm{b}}$, H. Cachier ${ }^{\mathrm{c}}$, Ph. Drobinski ${ }^{\mathrm{d}}$, E. Fréjafon ${ }^{\mathrm{e}}$, \\ C. Kottmeier ${ }^{\text {f }}$ P.E. Perros ${ }^{\mathrm{g}}$, V.-H. Peuch ${ }^{\mathrm{b}}$, J.-L. Ponche ${ }^{\mathrm{h}}$, \\ D. Robin ${ }^{\mathrm{i}}$, F. Saïd ${ }^{\mathrm{a}}$, G. Toupance ${ }^{\mathrm{g}}$, H. Wortham ${ }^{\mathrm{j}}$ \\ a Laboratoire d'Aérologie, UPS/CNRS, UMR 5560 Toulouse, France \\ ${ }^{\mathrm{b}}$ CNRM, Météo-France, Toulouse, France \\ ${ }^{\mathrm{c}}$ Laboratoire des Sciences du Climat et de l'Environnement, CEA/CNRS, Gif/Yvette, France \\ ${ }^{\mathrm{d}}$ Service d'Aéronomie, IPSL, Université Pierre et Marie Curie, Paris, France \\ ${ }^{\mathrm{e}}$ INERIS, Verneuil en Halatte, France \\ ${ }^{\mathrm{f}}$ Institut für Meteorologie und Klimaforshung, Universität Karlsruhe/Forschungzentrum, Karlsrhue, Germany \\ ${ }^{\mathrm{g}}$ LISA, Université de PARIS XII, UMR 7583 Créteil, France \\ ${ }^{\mathrm{h}}$ LPCA, Centre de Géochimie de la Surface, UMR7517, ULP/CNRS, Strasbourg, France \\ ${ }^{\mathrm{i}}$ AIRMARAIX, Marseilles, France \\ ${ }^{\mathrm{j}}$ LCE, Université de Provence, Marseilles, France
}

\begin{abstract}
In this paper, the "Expérience sur Site pour COntraindre les Modèles de Pollution atmosphérique et de Transport d'Emissions" (ESCOMPTE) program is presented. The ESCOMPTE program is used to produce a relevant set of data for testing and evaluating regional pollution models. It includes high-resolution (in space and time) atmospheric emission inventories and field experiments, and covers an area of $120 \times 120 \mathrm{~km}$, centered over the Marseilles-Berre area in the southeast of France during Summer 2001. This region presents a high occurrence of photochemical pollution events, which result from numerous industrial and urban sources of primary pollutants. From the dynamical characteristics of the area, sea-breeze circulation and channeling effects due to terrain features highly influence the location of the pollutant plumes. ESCOMPTE will provide a highly documented framework for dynamics and chemisty studies.

Campaign strategies and experimental set up are described. During the planning phase, existing modeling results helped defining the experimental design. The campaign involved surface measurement networks, remote sensing, ship-borne, balloon-borne, and airplane measurements. Mean standard meteorological parameters and turbulent fluxes, ozone, ozone precursors, photochemically active trace gases, and aerosols were measured. Five intensive observation periods (IOPs) were documented using a wide spectrum of instruments, involving aircraft (7) (one of them
\end{abstract}

\footnotetext{
* Corresponding author. Fax: +33-5-61-33-2790.
}

E-mail address: crob@aero.obs-mip.fr (B. Cros). 
equipped with a Doppler lidar, the others for in situ meteorological and chemical measurements), constant volume balloons (33), ozone lidars (5), wind profilers (15 sodars and radars), Doppler scanning lidar (1), radiosonde systems (at 4 locations), instrumented ships (2). In addition to the air quality networks from environmental agencies, 15 supplementary ground stations equipped for chemistry and/or meteorology and/or surface flux measurements, were operational. All instruments were calibrated and compared during a Quality Control/Quality Assurance (QC/QA) week, at the very beginning of the campaign.

Fifteen days were intensively documented during five IOPs, referenced as $1,2 \mathrm{a}, 2 \mathrm{~b}, 3$, and 4 . High pollution levels were encountered during sea-breeze conditions observed during IOPs $2 b$ and 3 , whereas IOPs $2 \mathrm{a}$ and 4 corresponded to moderate wind, and channeled plume regimes. In addition, hourly emissions inventories for all IOPs were established to complete data sets and to finalize the ESCOMPTE database (EDB).

Two other projects were associated to ESCOMPTE: urban boundary layer (UBL) and tropospheric water vapor content by GPS tomography $\left(\mathrm{GPS} / \mathrm{H}_{2} \mathrm{O}\right)$. They took advantage of the scientific environment provided by ESCOMPTE.

(C) 2004 Elsevier B.V. All rights reserved.

Keywords: Photo-oxidant; Air pollution; Emission inventories; Chemistry-transport modeling; Mediterranean area; ESCOMPTE

\section{Introduction}

Throughout the past 30 years, the impact of human activity on the atmosphere has been demonstrated, on global and local scales. The impact of air pollution on public health in urban areas and on vegetation in suburban/rural areas has become a major problem for our society. Processes involved with pollution problems are highly nonlinear, while chemistrytransport coupled modeling (CTM) tools permit to eventually get a grip upon these phenomena. This integrated approach and understanding should contribute to developing ozone abatement policy.

The development of combined photochemical and dynamical models is essential to better understand and predict air pollution events over urbanized and rural areas. So far, some urban models have been developed in Europe and the USA, but only a few have been compared against exhaustive field data. Comparison of the photochemical CALGRID model results (Yamartino, 1989) against actual measurements over the Los Angeles basin were presented by Kumar et al. (1994). The ozone pollution predictions were found to be underestimated, due to large discrepancies in the volatile organic compounds (VOC) and carbon monoxide (CO) emission assessment. The CALGRID model was linked with the transport prognostic model RAMS (Pielke et al., 1992) and tested over the Athens area (Pilinis et al., 1993). Comparison with data from the same region have been carried out with the KRAMM/DRAIS model system (Nester, 1995). Both studies emphasized the importance of reliable emission inventories, and of appropriate meteorological data. Sillman et al. (1995) similarly stressed the importance of using appropriate dynamic parameters over the urban area of Atlanta.

The contribution of biogenic VOC to total ozone production has been quantified with the KRAMM/DRAIS model in southwestern Germany (Vogel et al., 1995). They showed 
that the observed ozone concentrations could be best reproduced when biogenic VOC emissions were taken into account. Using the same model and ozone data from the experiments TRACT, FLUMOB and BERLIOZ, it was found that for 50\% (75\%) of the cases the difference between the measured and simulated ozone concentration is less than 8 ppbv (15 ppbv), respectively (Nester et al., 2002).

Important efforts in developing and improving mesoscale CTMs are currently implemented in France and in other European countries. Last model developments include schemes for aerosol component integration. Preliminary works confirm the important contribution of the regional scale processes on the pollutant concentrations observed at local scale (Pont and Fontan, 2000). This is particularly true for ozone which is dependent on reservoir species likely to be transported over long distances. There is now a large consensus within the scientific community on the fact that both local and regional contributions need to be taken into account where high ozone events in suburban and even rural areas are studied.

Comparisons of model calculations against field measurements require a complete and well-documented set of data, obtained with state of the art instrumentation for both, chemistry and dynamics measurements. Measurements routinely carried out from different air pollution networks cannot be used for this purpose since measurements strategies do not necessarily follow the same objectives. For example, species and parameters of interest for model comparison are generally not measured (e.g., PAN, aldehydes, actinic flux, turbulent flux...), and the measurement locations do not comply with mesoscale model requirements (data upwind, within and downwind the area of interest). In addition, nearly no upper-levels data is available.

Some data sets are available for large US cities such as Atlanta, Nashville, Pittsburgh, New York, and Houston (Hansel et al., 2002; Kleinman et al., 2002), whereas information available in Europe is more scarce and related to specific contexts. For instance campaigns recently conducted in Europe like MEDCAPHOTTRACE in 1997 (Ziomas, 1998), BERLIOZ in 1998 (Volz-Thomas et al., 2000; Corsmeier et al., in press), PIPAPO in 1998 (Neftel, 1999), ESQUIF from summer 1998 to winter 2000 (Menut et al., 2000a,b) were dedicated to the study of processes leading to air pollution events over the Athens, Berlin, Milano, and Paris surroundings, respectively.

In Europe, a variety of CTMs, from meso-to-regional scales, are currently available or being developed: i.e., LOTOS (Builtjes, 1992), EZM (Moussiopoulos, 1995), KAMMDRAIS (Nester et al., 1995), ECHAM-REMO (Roeckner et al., 1996), EURAD (Ebel et al., 1997), DMI-HIRLAM (Langmann and Graf, 1994), CLIME and ANA (San José et al., 1997). In France, similar advanced mesoscale CTMs have been recently developed: AZUR (IFP-LISA-EDF), MesoNH-chimie (Météo-France, LA), CHIMERE (IPSL) and MOCAGE (CNRM/Météo-France). In addition, several mesoscale CTMs developed in the USA are currently available for operational purposes: UAM4 and UAM5 (SAI) and the already mentioned CALGRID (University of California). However, in Europe, none of these models has been successfully tested to simulate pollution events over coastal areas in the Mediterranean by using a new comprehensive data set as provided by "Expérience sur Site pour COntraindre les Modèles de Pollution atmosphérique et de Transport d'Emissions" (ESCOMPTE). 
The main objective of the ESCOMPTE program is then to establish a detailed 4-D data base of primary pollutant emissions together with the dynamics and chemistry composition of the atmosphere during high pollution events. The data acquired during this program will then be used to address the following scientific issues:

- validate CTMs,

- understand relationship between emission of pollutants and airborne observed concentration,

- understand relationship between atmospheric dynamics and pollution level,

- understand relationship between air temperature and pollution rate,

- study urban-rural atmosphere interaction,

- determine aerosol influence on photochemical pollution.

Furthermore, the ESCOMPTE data set will be used to improve these models by providing a reaction scheme of photo-oxidants and particle interactions. Taking into account these interactions requires simultaneous measurements of gaseous and radical compounds, and of aerosol physical and chemical (organic and inorganic phases) properties.

ESCOMPTE data will help to provide answers to the following questions:

- What are the respective role of dynamics and chemistry on the pollution events?

- How to take into account urban emissions in regional or global models?

- Can an operational model of pollution events be developed?

- What is the respective contribution to observed pollution from local sources with respect to pollution from long range transport?

- What strategy policy must be set up in order to reduce photo-oxidant and particle concentrations?

The ESCOMPTE experimental environment provided background for two other scientific experiments; namely, Urban boundary layer (UBL) (Mestayer and Durand, 2002) and the atmospheric water vapor tomography by global positioning system (GPS) study $\left(\mathrm{GPS} / \mathrm{H}_{2} \mathrm{O}\right)$.

This paper gives an overview of the ESCOMPTE program. It presents the strategy and the different components of the program, i.e., emission inventory, field experiments, and modeling.

\section{Strategy of the ESCOMPTE program}

Every chemistry-transport model incorporates three principal modules: dynamics, chemistry, and emission. On one hand, the implementation of a project like ESCOMPTE required an important preparation phase, to select the zone and period of investigation and to define the experimental set up. The milestones of the preparatory phase consisted in achieving the emission inventory, conducting preliminary modeling studies, and performing a preliminary campaign. On the other hand, the experimental set up was designed to acquire data to constrain the models on each of these three modules. 


\subsection{The field site}

An $120 \times 120 \mathrm{~km}$ area around the city of Marseilles and the Berre pond, in southeastern France, has been selected to host the ESCOMPTE field campaign (Fig. 1). The selection criteria were based upon strong pollutant sources (urban and industrial) within the experimental area, high occurrence of photochemical pollution events and the presence of a dense, operational pollution monitoring network. This area best fulfills these criteria.

This site is constituted by three different zones:

- The urban area of Marseilles with 1.2 million inhabitants.

- The Fos-Berre zone around a pond located $15 \mathrm{~km}$ northwest of Marseilles and separated from the city by $300-\mathrm{m}$-high hills. It is characteristic of a strong industrial zone (refineries, power plants,...) surrounded by residential areas with important traffic.

- Rural areas either agricultural or covered by Mediterranean natural landscape.

The atmospheric circulation over this site is highly influenced by orography. On large scale, the Alps and Massif Central at times reinforce in the Rhône valley a strong northerly flow (Mistral). On a smaller scale, the ranges of smaller mountains parallel to the coastline (i.e., Sainte Baume, Sainte Victoire, Luberon, Ventoux) tend to channel the air masses in a west-east manner. The sea-land contrasts induce sea breeze during daytime, with advection of marine air masses as far as $100 \mathrm{~km}$ inland.

\subsection{Emission inventory}

The spatial resolution, and the list of chemical compounds of the ESCOMPTE inventories, have been determined to be consistent with further modeling applications and also with the main chemical schemes from models (Ponche et al., 2000a). Two sets of data have been prepared for the domain: yearly emissions with 1999 as the reference year, and hourly emissions for all the intensive observation periods (IOPs). The inventories relate any activity or source reliable to atmospheric emissions as far as available data and emission factors exist. The emission sources have been split according to classifications from the European Environmental Agency or European research programs: the Selected Nomenclature for Air Pollution (SNAP) at the highest existing level (252 different activities and processes), the Nomenclature for Air Pollution of Fuels (NAPFUE) and the COPERT classification for the mobile sources. The sources can roughly be divided into four types: (1) the stationary combustion sources (including industry, residential, and service sectors) and the industrial processes, (2) the mobiles sources: i.e., road, railway, air, and fluvial/sea traffics, (3) waste treatment and disposal and, (4) biogenic/natural sources (including agriculture, rearing, forest, wetlands, and sea). The list of chemical species and groups of species has been established according to the needs of the chemical part of the models (chemical mechanisms) which are mainly used in Europe. This list of 81 compounds has been divided into five classes of priority. Priorities 1 and 2 involve the major species necessary for the tropospheric chemistry modeling; the compounds listed in priority 3 concern other species, which can have an interest for atmospheric chemistry. The other priorities (4 and 5) involve the other chemical compounds, which do not have a 


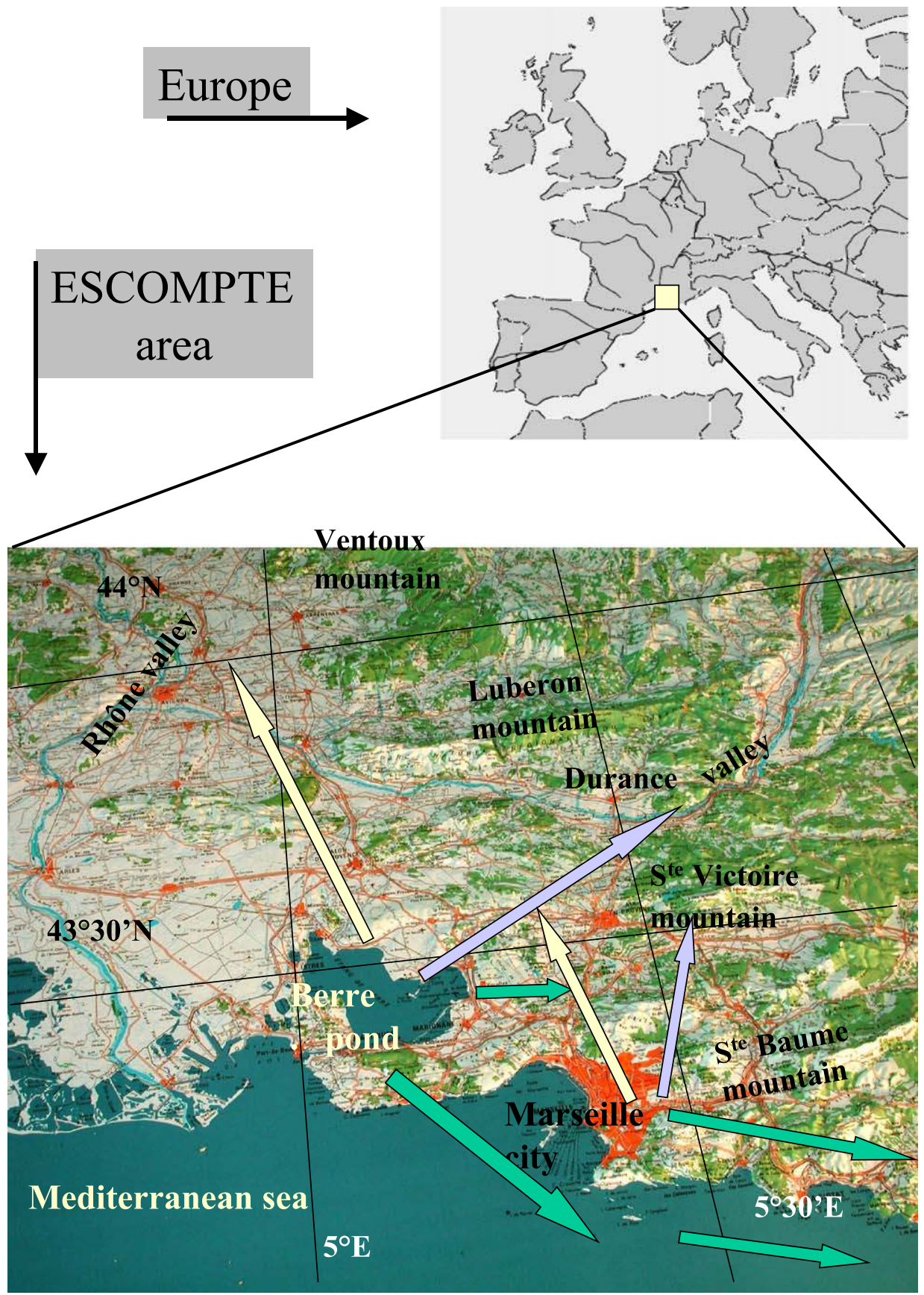

Fig. 1. The ESCOMPTE domain and the prevailing winds from Marseilles and Berre pond associated with polluted episodes (green arrow: sea breeze with light to moderate Mistral, lavender blue arrow: pure sea breeze and yellow arrow: southerly wind). 
direct interest in this study. The main specifications of the emission inventories are summarized in Table 1.

The general methodology that will be applied for the ESCOMPTE inventories has already been defined (François et al., 2000) and validated in several previous studies on emission inventories (Ponche et al., 1998, 2000b). The bottom-up approach methodology is used to calculate the emissions, where the required data are available. This approach takes into account the highest degree of relevant local information available. The spatial distribution of the emissions has been performed with a Geographical Information System (GIS) and with the help of specific databases such as land use, road network, etc.

All the relevant data for checking, updating, and classifying the emission inventories will be integrated in a final data base which does not only include the final emission values but also intermediate results and uncertainty estimates, allowing efficient tracking of both systematic errors and potential miscalculations. Furthermore, follow-up studies have been started to investigate and improve the different procedures of emission computation, including special interest on updating of the data. One of the main goals is to fulfill a better integration of GIS, Data Base Management System (DBMS), and emission computation procedures with a mouse driven and user friendly Graphical User Interface (GUI). The final user emission database for the ESCOMPTE program, extracted from this detailed emission database, only contains the emission values per grid cell $(1 \times 1 \mathrm{~km})$, per year (for 1999) or hour (for the 2000 and 2001 IOPs), and per chemical species. As an example of the mobile emissions per year from the ESCOMPTE domain the map in Fig. 2 gives the road traffic emissions of volatile organic compounds (VOC) for 1999.

\subsection{Preliminary campaign}

The preparatory campaign (Summer 2000) was conducted with a limited set of instruments and over a short period. Three weeks had been selected, from June 19 to July 9, 2000. The objectives were to explore 4-D $(x, y, z, t)$ concentration fields to assess orders of

Table 1

Specifications of the ESCOMPTE emission inventories

Extension of the domain

UTM coordinates (north west corner)

Reference year

Spatial resolution (grid cell size)

Time resolution

Source categories

Classifications of the activity/sources

Chemical species and groups of species

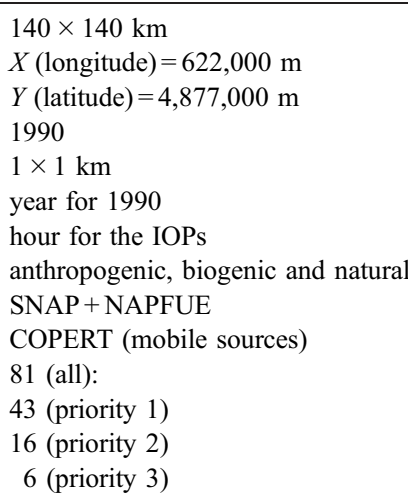




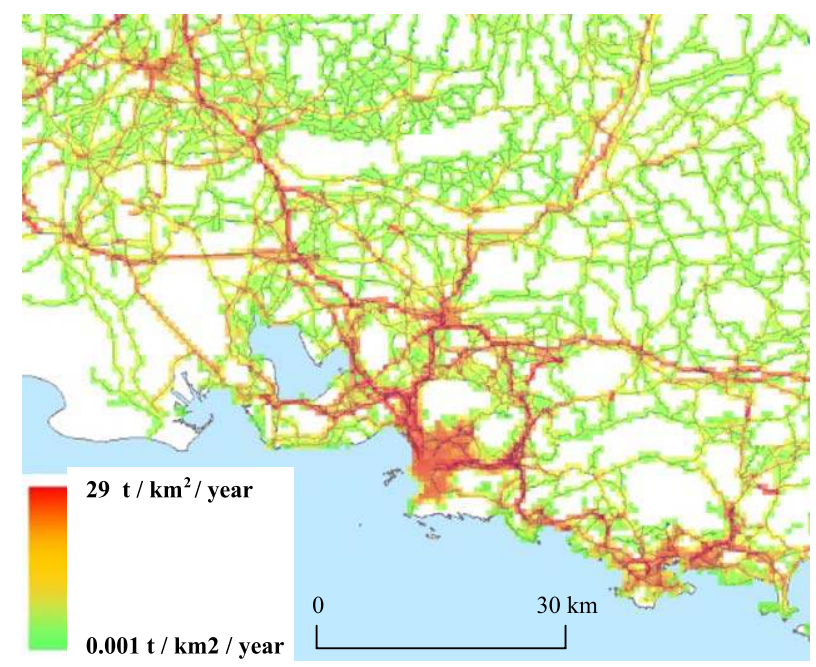

Fig. 2. Map of VOC road traffic emissions for 1999 in the ESCOMPTE domain. The color scale denotes values in ton-per-square kilometer by year $\left(\mathrm{t} / \mathrm{km}^{2} /\right.$ year$)$.

magnitude of critical constituents and to evaluate the pollutant plume dimensions and their location in relation to the meteorological characteristics, so as to determine the extent of the domain of interest. The other aims were to qualify plume trajectory numerical tools, to test operational procedures for IOPs triggering, and to test the feasibility of airborne operations, given the conditions imposed by the air traffic control. Ground-based equipment was operational over the area from the beginning (June 19), whereas airborne measurements were active only during the so-called IOP0, corresponding to a pollution event (June 29July 1). The ARAT Fokker 27 equipped by the "Institut des Sciences de l'Univers (INSU)", and the Piper-Aztec of Météo-France were the two aircraft in operation. Their equipment is presented below in Section 3.1. Moreover, seven constant-volume balloons (CVB) were released either from Martigues or from northern Marseilles to track pollutant plumes coming from the industrial and urban area, respectively. Localized by GPS, they were equipped with a classic radiosonde (pressure, temperature and moisture measurements), while two of them had an additional ozone probe.

Permanent networks include Météo-France and air quality control agencies (AIRMARAIX and AIRFOBEP) sites. Three mobile stations were dedicated to the pollutant measurements over the experimental domain. Aerosol measurements were performed from June 19 to 26 on four sites.

A measurement station was operated onboard of the ferry boat linking Corsica to the continent in order to document concentrations of $\mathrm{NO}_{\mathrm{x}}, \mathrm{SO}_{2}$ and $\mathrm{O}_{3}$ in the marine boundary layer.

A radiosonde station and a UHF radar (wind profiling system) were installed in Martigues, close to the Berre pond. A small VHF Doppler radar and another Doppler UHF radar were operated by "Laboratoire des Sondages Electromagnétiques de l'Environne- 
ment Terrestre" (LSEET) in Toulon, in the southeastern part of the domain. (For a more detailed description of the instruments see Section 3, hereafter.)

The prevailing meteorological conditions during this preliminary campaign were unfavorable for well defined polluted episodes. However, the 3 days during IOP0 presented three different wind regimes (NW with moderate "Mistral" on June 29, W on June 30, and S on July 1), allowing interesting numerical simulation of different situations for pollution plumes.

The IOP operating scheme was efficient and the planned flight operations were satisfactorily performed.

\subsection{Chemistry-transport modeling of previous pollution events}

Modeling was a key component for the preparation and planning of ESCOMPTE. From an early stage, preparatory photochemical simulations were carried out with objectives to contributing to the following questions:

- What is the geographical extent of pollution events in the Marseilles region? Where should the measurements of dynamics and chemistry focus?

- What are the expected variation ranges for measured species in the so-called "sources" (urban and/or industrial), "intermediate"(sub-urban), and "background" (rural) areas?

and following decisions:

- Selecting locations of ground sites, constant volume balloon and radiosonde stations, as well as design of a comprehensive set of flight plans.

- Assessing of current model performances, by using existing emissions inventories (EDGAR2.0, EMEP or GENEMIS) and comparing the output to surface monitoring networks data.

Several chemistry and transport models were used for these numerical experiments. They cover ranges from local scale to continental and global ones. The used models and their main characteristics are listed in Table 2. Selected regional summer photochemical episodes of 1999, and preliminary campaign IOP0 days were studied. Together with the regional air quality networks, these studies highlighted three main meteorological regimes associated with heavily polluted episodes (Fig. 1). The first one corresponds to a light synoptic southerly flux, sometimes associated with "classic" sea breeze approximately perpendicular to the shoreline. In this case, the urban emissions from Marseilles often merge with the industrial emissions and secondary pollutant maxima developed in the Rhône Valley. These meteorological conditions generally do not lead to an accumulation of pollutants even if they prevail for several days, due to the weak contribution of the large-scale transport of pollution. The second one is probably the most interesting: it corresponds to land/sea breeze events, with no or very light synoptic wind. Pollutants are transported inland, and sometimes in connection with orography, the two plumes merge between Aix-en-Provence and the entrance of the Durance Valley (Cadarache). If meteorological conditions prevail for several days (as was the case during IOP $2 \mathrm{~b}$ of 


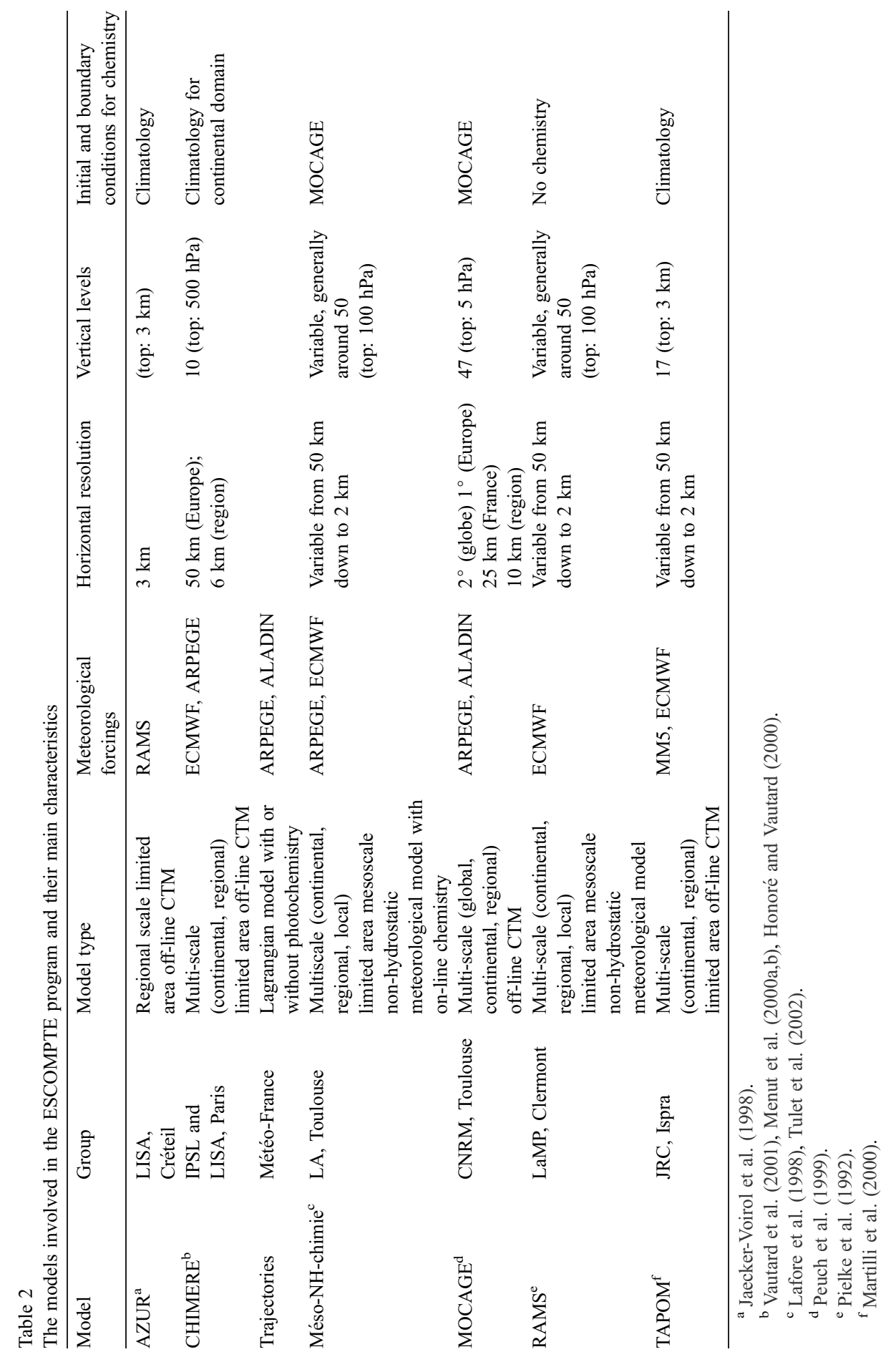


the 2001 campaign), an accumulation of pollutants is predicted by the models. Hence, these conditions seem to lead to the most intense and generalized polluted episodes in the region. The third one is the most frequent: a sea breeze associated with light to moderate Mistral northwesterly wind leading to plumes going eastward and along the coastline. Secondary pollutants maxima are encountered in the vicinity of Toulon, and models predict that plumes will go over the Mediterranean sea. The first 2 days of the IOP0 were of this type. The Mistral component prevents the accumulation of pollutants, and ozone levels are often lower than $100 \mathrm{ppbv}$.

The main conclusions that were of interest for the design of the measurement strategy are echoed in the experimental set-up used during the campaign. They are listed below:

- Intense morning photochemical activity occurs at a relatively short distance $(20-30 \mathrm{~km})$ from the emissions zone; the most heavily equipped surface sites should hence be located in the intermediate zone;

- There is a need to document the levels of pollutants over the sea; boundary conditions may be of importance, especially for type-3 events. Fig. 3 presents the geographical Probability Distribution Function (\%) of air masses, between 1200 and 1800 UTC before their arrival in Marseilles and, respectively, after their departure from Marseilles. This distribution is computed on the basis of 6-hourly back-and-forward threedimensional trajectories for the months June-July 1998 and 1999. Interestingly, air masses arriving in Marseilles present preferential localizations along the Rhône Valley (city of Lyon and chemical plants) and over the Mediterranean, ashore from the

a) Arriving in Marseilles

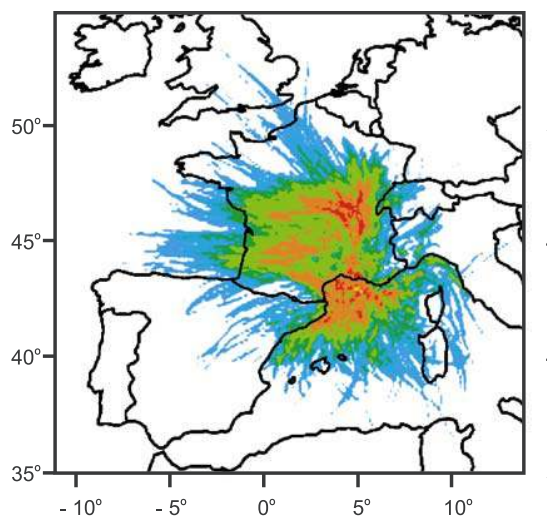

b) Departing from Marseilles

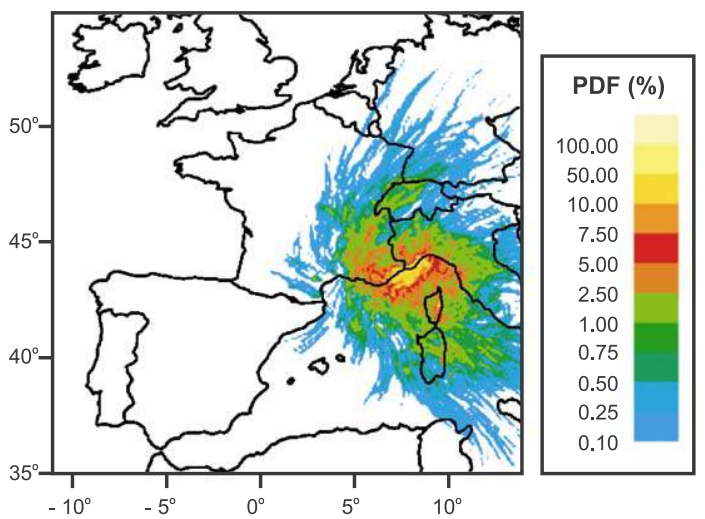

Fig. 3. Probability distribution function (PDF, \%) of the geographical localization of back (a) and forward (b) trajectories, between 1200 and 1800 UTC before their arrival in Marseilles and, respectively, after their departure from Marseilles. Winds are from Météo-France ALADIN operational meteorological model $\left(0.1^{\circ}\right.$ horizontal resolution). Ten vertical arrival and departure points are taken between 10 and $2000 \mathrm{~m}$ every $6 \mathrm{~h}$ for the periods June-July 1998 and 1999, resulting in a total number of approximately 5000 back and forward trajectories. The number of trajectory points in each vertical column of a $0.1^{\circ}$ by $0.1^{\circ}$ mesh are normalized by the total number of points to provide the PDF. 
Barcelona region. Air masses departing from the ESCOMPTE domain preferentially go along the coastline and over the Gulf of Genoa; hence, they could make a contribution to the pollution in Northern Italy and down to Tuscany;

- The ozone surface levels are reasonably simulated by the different models, which is not the case for primary pollutants. The city of Marseilles and the vicinity of the Berre pond, which are densely equipped by regional air quality monitoring networks, present diurnal profiles that are specially challenging for the models (large quasi-ponctual emissions due to petrochemical plants and highways,...), using existing emissions inventories. In addition, local dynamical features such as small scale recirculation and breezes (i.e., sea, orography, city,...) bring much complexity in the different plumes interacting in the "source" zone. The need for detailed anthropogenic and natural emission data, at high horizontal and temporal resolutions were confirmed.

During the summer of 2001 two of the models (CHIMERE and MOCAGE) were run in routine forecast mode (up to 2 days in advance), in order to help in the decision of launching IOPs and in the selection of the best adapted flight strategies (see Section 4.2).

\section{Experimental set up of the main campaign}

Overall the main objectives of ESCOMPTE were accomplished through a coordinated program of measurements by more than 100 scientists from France, Germany, Switzerland, Italy, the United States, and Canada. The field experiment was conducted between June 4 and July 13 over a $120 \times 120 \mathrm{~km}$ area. Aircraft flights, together with tethered and constant volume balloons, radiosonde systems and remote sensing measurements, associated with the more continuous surface measurements, provided the most comprehensive picture of atmospheric dynamics and chemistry over the French Mediterranean area. A list of ESCOMPTE (and associated programs) with principal investigators and measurement parameters is presented in Appendix A.

\subsection{Altitude measurements}

\subsubsection{Aircraft measurements}

One of the most important component of ESCOMPTE was a series of 125 flights representing more than $300 \mathrm{~h}$ of flight time. Three French research aircraft (Fokker 27 ARAT run by INSU, Merlin IV and Piper Aztec 23, both operated by Météo-France) and three German research aircraft (Dornier 128 operated by IMK, Falcon 20 equipped with the French-German Doppler lidar WIND and operated by DLR, and ULM from IFU) participated in the field experiment. A seventh private aircraft was equipped with a CCD IR camera to measure the Marseilles radiometric surface temperature (UBL project).

The ARAT, Dornier, Merlin, and Piper Aztec 23 performed classic dynamical and thermodynamical slow and fast measurements, as well as radiation measurements including the $\mathrm{NO}_{2}$ photolysis rate $J_{\mathrm{NO}_{2}}$. They were also equipped for chemical measurements such as $\mathrm{NO}_{\mathrm{x}}, \mathrm{NO}_{\mathrm{y}}, \mathrm{O}_{3}, \mathrm{CO}$ or $\mathrm{CO}_{2}$. In addition, the Fokker 27 ARAT could measure 
particle properties with several sensors. The ULM also provided temperature, humidity, $\mathrm{O}_{3}, J_{\mathrm{NO}_{2}}, J_{\mathrm{O}(1 \mathrm{D})}$ and particle measurements. The airborne equipment is presented for each plane in Table 3.

The flights corresponded to four types of activities (Fig. 4):

- Exploration flights: 2D approach to retrieve chemical compounds and meteorological parameters on a $120 \times 120 \mathrm{~km}$ area by flying constant level parallel legs. Two aircraft

Table 3

Measured parameters onboard during ESCOMPTE 2001

\begin{tabular}{|c|c|c|}
\hline & Measured parameters & Instrument \\
\hline ARAT & $\mathrm{O}_{3}$ & Thermo Electron Inst 49 \\
\hline $\begin{array}{l}\text { INSU (Institut National } \\
\text { des Sciences de l'Univers) }\end{array}$ & $\begin{array}{l}\mathrm{NO}, \mathrm{NO}_{2}, \mathrm{NO}_{\mathrm{y}}, \mathrm{PAN}, \mathrm{HNO}_{3} \\
\text { VOC }(\mathrm{C} 5-\mathrm{C} 10) \\
\mathrm{CO} \\
J_{\mathrm{NO}_{2}} \\
\text { Nephelometer } \\
\text { Aerosols } \\
\text { Black Carbon } \\
P, T, Q, \text { wind } \\
\text { Turbulence: velocity, } T, Q, \mathrm{O}_{3} \\
\text { Radiation: visible and IR up } \\
\text { and down, Barnes } \\
\text { Video camera }\end{array}$ & $\begin{array}{l}\text { MONA (Chemiluminescence) } \\
\text { Trapping on cartridges } \\
\text { Modified Thermo Electron } \\
\text { Meteo-Consult } \\
\text { TSI } \\
\text { PCASP, TSI } \\
\text { Aethalometer } \\
\text { Aircraft equipment } \\
\text { Aircraft equipment, Güsten } \\
\text { Aircraft equipment }\end{array}$ \\
\hline MERLIN (Météo-France) & $\begin{array}{l}\mathrm{O}_{3} \\
J_{\mathrm{NO}_{2}} \\
\mathrm{NO}, \mathrm{NO}_{2}, \mathrm{NO}_{y}, \mathrm{PAN}, \mathrm{HNO}_{3} \\
\text { VOC }(\mathrm{C} 5-\mathrm{C} 10) \\
\mathrm{CO} \\
P, T, Q, \text { wind } \\
\text { Turbulence: velocity, } T, Q \\
\text { Radiation: visible and IR up } \\
\text { and down, Barnes }\end{array}$ & $\begin{array}{l}\text { Thermo Electron } \\
\text { MeteoConsult } \\
\text { NOxTOy Metair (Luminol) } \\
\text { Trapping on cartridges } \\
\text { Thermo Electron } \\
\text { Aircraft equiptment }\end{array}$ \\
\hline ATZEC (Météo-France) & $\begin{array}{l}\mathrm{O}_{3} \\
\mathrm{NO}, \mathrm{NO}_{2}, \mathrm{NO}_{\mathrm{y}}, \mathrm{PAN}, \mathrm{HNO}_{3} \\
\mathrm{VOC}(\mathrm{C} 5-\mathrm{C} 10) \\
P, T, Q, \text { wind }\end{array}$ & $\begin{array}{l}\text { Environment SA } \\
\text { NOxTOy Metair (luminol) } \\
\text { Trapping on cartridges } \\
\text { Aircraft equipment }\end{array}$ \\
\hline DORNIER 128 (IMK) & $\begin{array}{l}\mathrm{O}_{3} \\
\mathrm{NO}, \mathrm{NO}_{2}, \mathrm{NOy}, \\
\mathrm{CO}, \mathrm{CO}_{2} \\
P, T, Q, \text { wind } \\
\text { Turbulence: velocity, } T, Q, \mathrm{O}_{3} \\
\text { Radiation: Vis., IR up and down } \\
\text { Surface temperature, NDVI }\end{array}$ & $\begin{array}{l}\text { Environnement SA } \\
\text { NOxTOy Metair (Luminol) } \\
\text { Aero Laser 5001, LICOR } \\
\text { Aircraft equipment } \\
\text { Aircraft equipment Güsten } \\
\text { Kipp and Zonen } \\
\text { Scanning Heitronics KT15, } \\
\text { AWI CLS }\end{array}$ \\
\hline MIFU (ULM) (IFU) & $\begin{array}{l}\mathrm{O}_{3} \\
J_{\mathrm{NO}_{2}}, J_{\mathrm{O} 1 \mathrm{D}}, \text { Global Radiation } \\
\text { Aerosol (number, size) } \\
\text { Nephelometer }\end{array}$ & $\begin{array}{l}\text { UV photometer } \\
\text { Radiometers }+ \text { LICOR } \\
\text { Laser, FSSP } \\
\text { TSI }\end{array}$ \\
\hline $\begin{array}{l}\text { FALCON } 20 \text { (DLR) } \\
\text { AZTEC } 28 \text { (SAAL) }\end{array}$ & $\begin{array}{l}\text { 3D Wind } \\
\text { Surface temperature }\end{array}$ & $\begin{array}{l}\text { WIND Doppler Lidar } \\
\text { Inframetrics } 760\end{array}$ \\
\hline
\end{tabular}



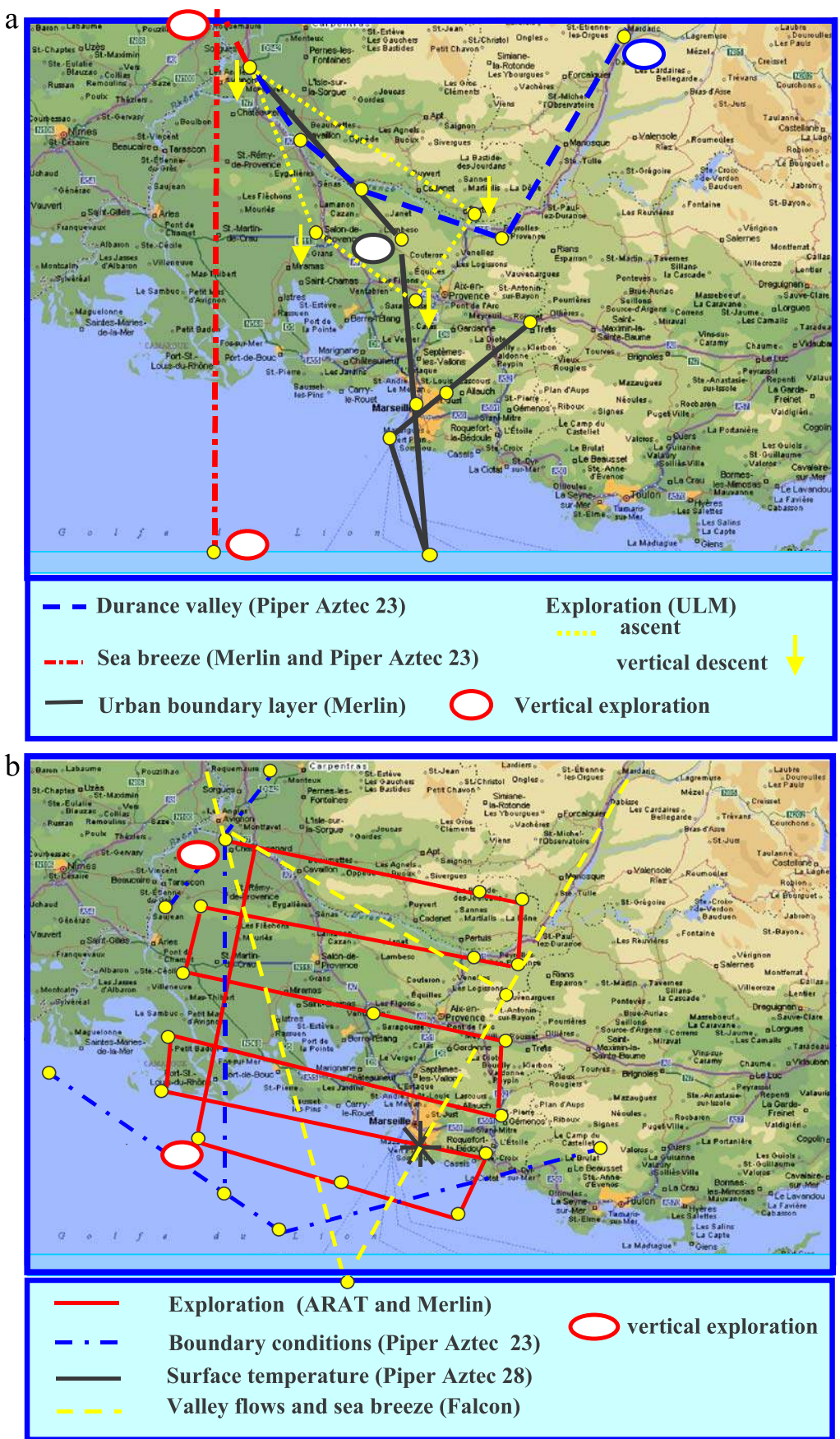


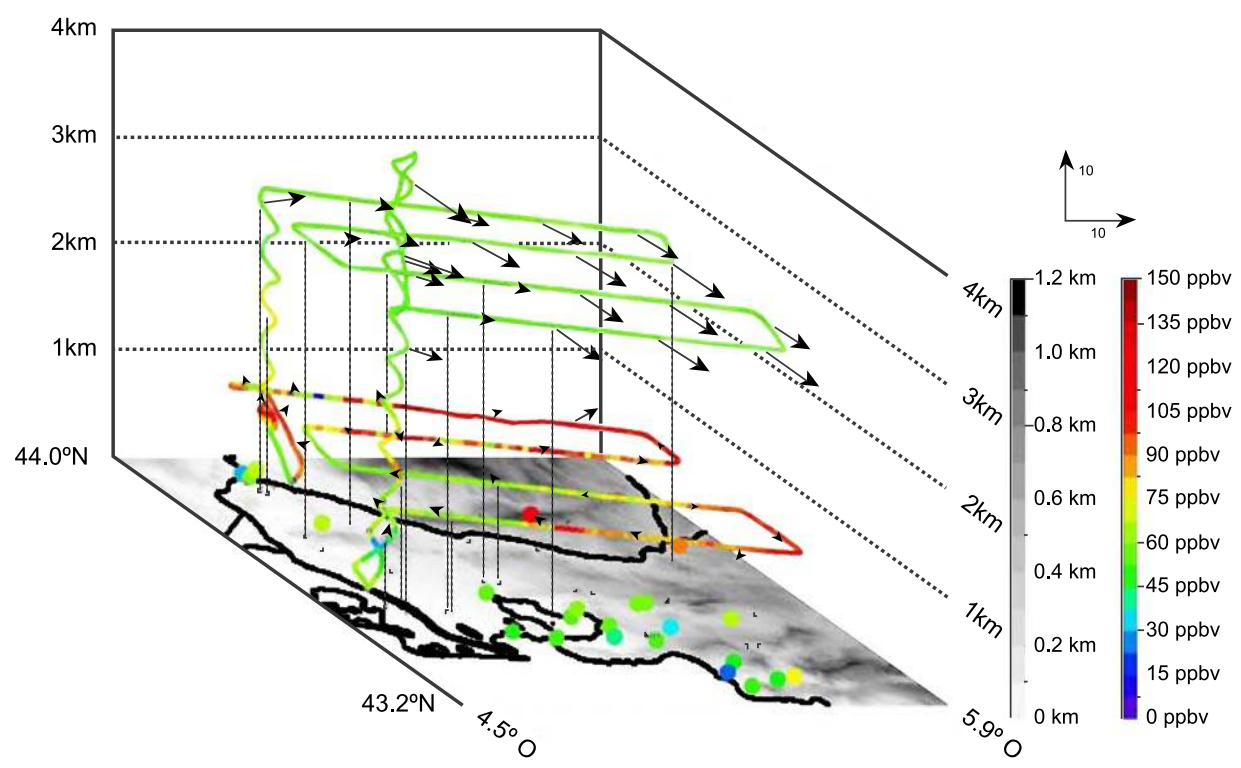

Fig. 5. An afternoon flight from the Dornier (1402 to 1746 UTC) inside both boundary layer (1000 m ASL and free troposphere ( $2800 \mathrm{~m} \mathrm{ASL}$ ) and a vertical exploration up to $4300 \mathrm{~m}$ ASL). The color scale denotes values of ozone concentration in parts per billion by volume (ppbv) and the grey scale the relief altitude in $\mathrm{km}$.

could be used simultaneously to explore several levels. These kinds of flights were completed by a vertical description of the boundary conditions at the plume entrance of the area. Fig. 5 displays an illustration of a Dornier afternoon flight (1402 to 1746 UTC) inside both boundary layer (1000 m ASL) and free troposphere (2 $800 \mathrm{~m} \mathrm{ASL})$ and a vertical sounding up to $4300 \mathrm{~m}$. We see that the Marseilles and Fos-Berre plumes are shifted by the sea breeze and channeled by relief and valleys to the northeast with high ozone concentrations reaching $150 \mathrm{ppbv}$. The stable layer capping the boundary layer exhibits homogeneous ozone concentration ranging between 60 and 75 ppbv.

- Sea-breeze flights: characterize a vertical plane, crossing the coast, and extending 50 and $120 \mathrm{~km}$ over sea and land, respectively.

- Plume flights: study the plume extent within the Durance valley.

- Urban boundary-layer flights: study of the variability between Marseilles and the surroundings, describing two vertical planes crossing over the city. A star-shaped flight track was also flown over the city to measure the surface temperature and the directional effects.

Fig. 4. Horizontal track of the flights performed by the aircraft during the ESCOMPTE field experiment. (a) Flight paths of Merlin and Piper Aztec to study the sea breeze (dashed red line), the extent plume in the Durance valley (dashed blue line) and the urban boundary layer (black line); the dotted yellow line is the flight path of ULM. (b) Flight paths of ARAT, Dornier and Merlin to explore the ESCOMPTE domain (red line); Piper Aztec 23 and 28, respectively, determine the boundary conditions (dashed blue line) and the surface temperature (black line); the dashed yellow line is the flight path of Falcon 20 to document the valley fluxes (Rhône and Durance) and the sea breeze. The circle lines represent the vertical exploration of the planes. 


\subsubsection{Constant volume balloons (CVBs) experiments}

The aim of this experiment was to follow pollutant plumes, and to investigate its thermodynamics and physicochemical time evolution. This was performed with CVBs, operated by the "Centre National d'Etudes Spatiales" (CNES) and instrumented by the "Laboratoire d'Aérologie" and "Météo-France". The CVBs, located by GPS were equipped with thermodynamics and ozone sensors, and flied at a constant density level in the atmospheric boundary layer. These CVBs constitute in situ means to validate the highresolution trajectories from models output.

There were 33 CVB flights during ESCOMPTE campaign, 15 of which were equipped with ozone sensors. Fig. 6 presents the preliminary results of flights during IOP0, in particular the time evolution along the CVB trajectories and the comparison with numerical simulations.

\subsubsection{Tethered balloon}

A tethered balloon was used at the "Observatoire" site (Marseilles) to measure pressure, temperature, water vapor content, wind speed and direction, and ozone concentration, from the ground up to $200 \mathrm{~m}$. The soundings lasted roughly $30 \mathrm{~min}$. The turbulence was so strong, even under weak winds, that soundings could only be performed before 1100 UTC, while the anchor guy broke on June 21. New equipment was used afterwards but without any wind sensor.

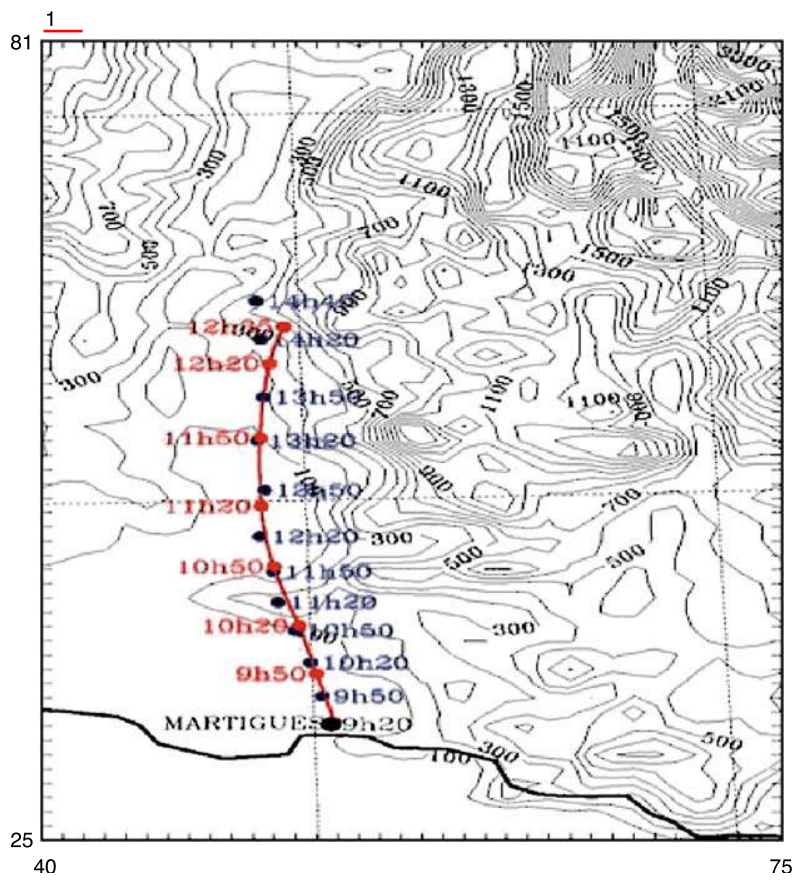

Fig. 6. Constant volume balloon trajectory and comparison with numerical simulation. This balloon was launched on July 1, 2000, during IOP0, from Martigues and flew more $5 \mathrm{~h}$ between 600 and $900 \mathrm{~m}$. The simulation (in red) follows quite well the balloon (in blue) but with a distance more rapidly covered. 


\subsubsection{Radiosondes}

Four sites were equipped with radiosonde systems. One was located at the " Observatoire de Haute Provence", in the northern part of the domain. It is an operational station, which belongs to the ozone profiling network. Routine operation consists in performing an ozone (together with temperature and moisture) profiling every Wednesday morning at 1000 UTC. Nevertheless, during ESCOMPTE, this sounding was sometimes operated at another weekday, in order to be within (or close to) an IOP.

Two rawinsonde systems were operated by IMK, the first one was located at Vinon/ Verdon, in the Durance valley (northeastern part of the area), and the second one at the StRemy flying ground, close to "Les Alpilles", hills in the southwestern part. At "Aix-lesMilles", in the core of the ESCOMPTE domain, the CNRM operated a rawinsonde system, which had ozone profiling abilities. A fifth radiosonde system through the UBL program permitted occasional measures of temperature and moisture profiles at the "Observatoire de Marseille".

\subsubsection{Remote sensing measurements}

The main objective of the remote sensing instruments (Table 4) was to characterize the dynamics of the wind profiles, the height of the planetary boundary layer obtained both with radar or sodar, and the ozone stratification and concentration obtained by lidar. Several precise locations were defined, combining a radar or sodar with a lidar. It was organized in order to create a multi-scale (local and regional) remote sensing network on emission zones where photochemical processes are dominant, on intermediate zones where ozone is mainly generated by transport processes, and on rural zones in order to give information on the domain limits.

Five ozone lidars (two of them capable of angular scanning) and 15 wind profilers (radar or sodar) were present during this campaign. One VHF radar and one UHF radar were also coupled to a RASS, to measure the temperature profile. Co-localized with an ozone and aerosol angular lidar (INERIS-ULCO), a wind angular lidar (LVT-SA) was present, north of Marseilles, giving an angular scan of aerosols but also wind direction and radial speed.

Measurements were obtained during all intensive observation periods and, for some of them, throughout the ESCOMPTE campaign. For example, a vertical ozone profiler (INERIS), combined with a sodar (IMK) (localized in Cadarache, an intermediate zone in the Durance valley) gave measures every 15 min from July 8 to July 14, with high data quality.

These instruments provided information on a multi-scale level: locally with spatial resolution from hundreds of meters to kilometers and at mesoscale from kilometers to hundreds of kilometers, which fulfilled the scale requirements for the ESCOMPTE campaign. The remote sensing instrumentation and the ESCOMPTE surface stations are displayed in Fig. 7.

\subsection{Surface measurements}

\subsubsection{Air quality networks}

Many measurement stations in the ESCOMPTE domain are run by the local Air Quality Agencies ( 29 by AIRMARAIX and 26 by AIRFOBEP) to monitor atmospheric pollution. 
Table 4

Specifications of remote-sensing instruments

\begin{tabular}{|c|c|c|c|c|c|c|c|c|c|}
\hline Parameters & Method & & $\begin{array}{l}\text { Time } \\
\text { resolution } \\
\text { (s) }\end{array}$ & $\begin{array}{l}\text { Spatial } \\
\text { resolution } \\
\text { (m) }\end{array}$ & $\begin{array}{l}\text { Altitude } \\
\text { range }(\mathrm{m})\end{array}$ & & & & Used \\
\hline $\mathrm{O}_{3}$, aerosol & $\begin{array}{l}\text { Angular } \\
\text { lidar }\end{array}$ & fixed & 2 & $50-200$ & $0-3000$ & Done & $\begin{array}{l}2 \mu \mathrm{g} / \mathrm{m}^{3} \\
0.01 \mathrm{~km}^{-1}\end{array}$ & $5 \%$ & IOP, \\
\hline $\mathrm{O}_{3}$, aerosol & $\begin{array}{l}\text { Vertical } \\
\text { lidar }\end{array}$ & fixed & 30 & $200-1000$ & $500-7000$ & Done & $\begin{array}{l}2 \mu \mathrm{g} / \mathrm{m}^{3} \\
0.01 \mathrm{~km}^{-1}\end{array}$ & $10 \%$ & IOP \\
\hline $\mathrm{O}_{3}$, aerosol & $\begin{array}{l}\text { Vertical } \\
\text { lidar }\end{array}$ & mobile & 3 & $100-200$ & $100-3000$ & Done & $\begin{array}{l}3 \mu \mathrm{g} / \mathrm{m}^{3} \\
0.01 \mathrm{~km}^{-1}\end{array}$ & $10 \%$ & $24 \mathrm{~h} / 24$ \\
\hline $\begin{array}{l}\text { Radial } \\
\text { wind, } \\
\text { aerosol }\end{array}$ & $\begin{array}{l}\text { Wind } \\
\text { Lidar }\end{array}$ & fixed & 2 & $200-1000$ & $0-6000$ & & & & $\begin{array}{l}\text { IOP, } \\
\text { CLU }\end{array}$ \\
\hline $\mathrm{S}, \mathrm{D}, \mathrm{W}$ & $\begin{array}{l}\text { UHF } \\
\text { radar }\end{array}$ & fixed & 5 & $75-375$ & $150-4000$ & & & & $24 \mathrm{~h} / 24$ \\
\hline S, D, W & $\begin{array}{l}\text { VHF } \\
\text { radar }\end{array}$ & fixed & 15 & 375 & $1500-15000$ & & & & $24 \mathrm{~h} / 24$ \\
\hline $\mathrm{S}, \mathrm{D}, \mathrm{W}$ & $\begin{array}{l}\text { Mini } \\
\text { VHF } \\
\text { radar }\end{array}$ & fixed & 5 & 300 & $600-5000$ & & & & $24 \mathrm{~h} / 24$ \\
\hline $\mathrm{S}, \mathrm{D}, \mathrm{W}$ & Sodar & fixed & $15-30$ & $20-50$ & $50-800$ & & & & $24 \mathrm{~h} / 24$ \\
\hline S, D, W & $\begin{array}{l}\text { Mini } \\
\text { sodar }\end{array}$ & fixed & 15 & 5 & $10-100$ & & & & $24 \mathrm{~h} / 24$ \\
\hline
\end{tabular}

These two agencies were used as a starting point for the development of the surface measurement network for the ESCOMPTE campaign. While stations provided basic data (Fig. 8) some provided additional data following ESCOMPTE requirements. It is possible to distinguish four kinds of stations: meteorological stations, trace species flux measurement stations, aerosol stations, and chemical stations (see Table 4).

\subsubsection{Meteorological stations}

There were 14 meteorological stations spread over the ESCOMPTE area, two of them in the frame of the UBL program. These stations provided pressure, temperature, relative humidity, wind speed and direction, short wave and/or total radiation measurements. In addition, the surface energy budget was measured in nine of these stations. Temperature and relative humidity were also measured onboard three mobile cars on rural sites, and on a UBL network of 20 sensors spread over Marseilles agglomeration. UV radiation was measured at five sites.

\subsubsection{Trace-gas flux stations}

The main objectives from these stations were to test the accuracy of the emission inventory concerning biogenic parameters and to determine the quantity of matter eliminated from the atmospheric reactor by deposition. These measurements were carried out on rural sites (maize crop, forest of white oaks, steppe, and "garrigue" mainly 

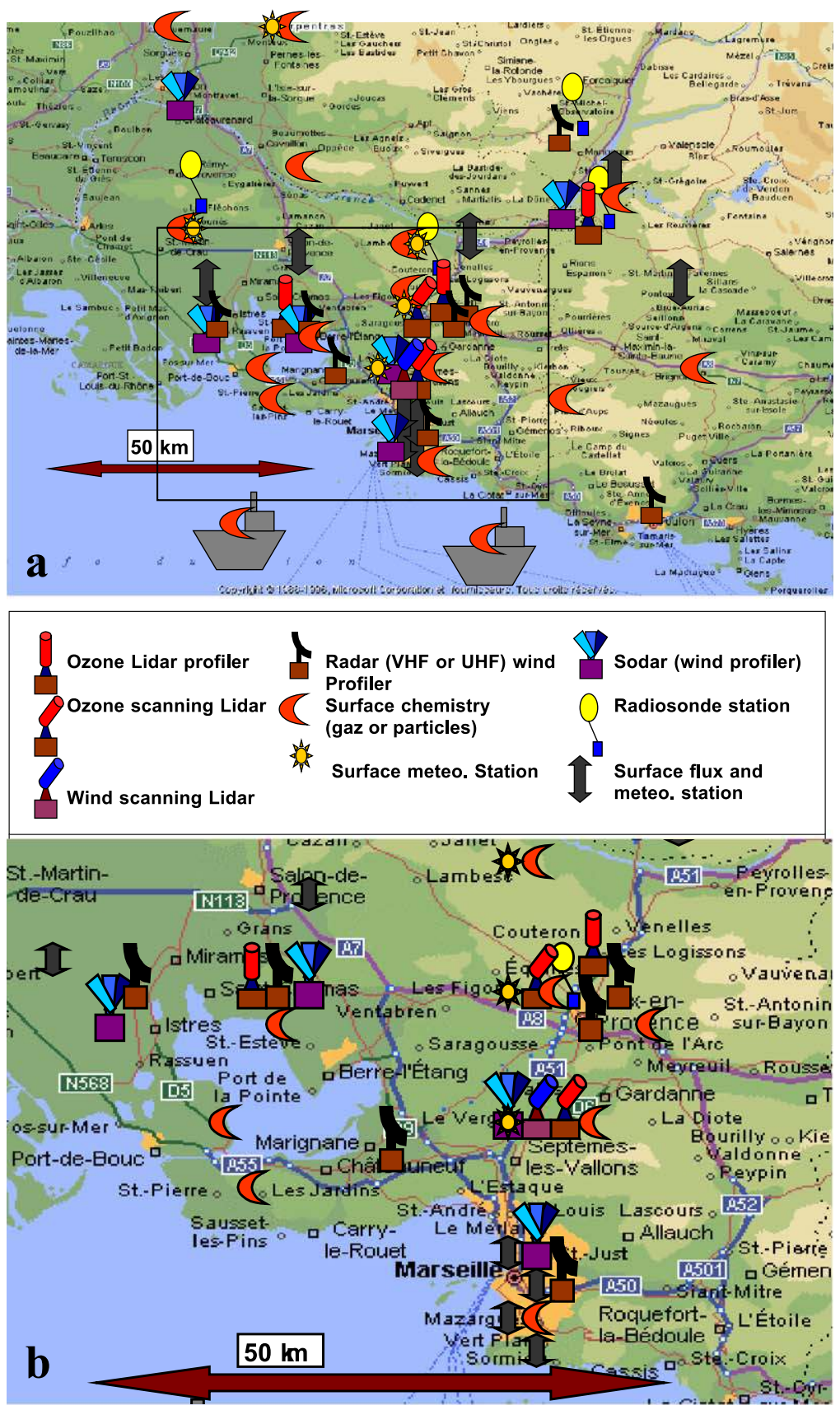

Fig. 7. Locations of remote sensing instruments and ESCOMPTE surface stations: (a) in the whole domain, (b) near the emission zones during the field experiment. 

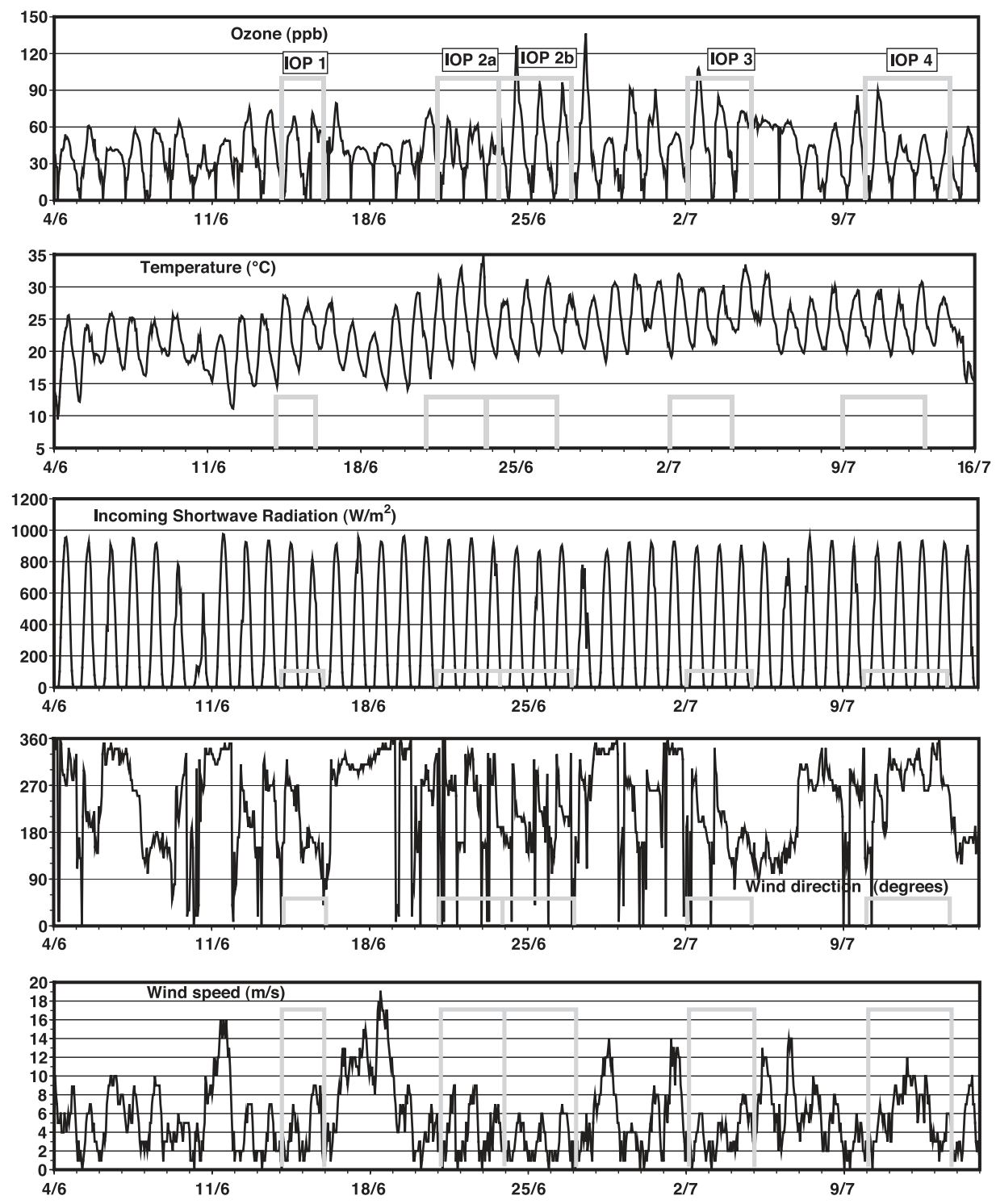

Fig. 8. Time series of ozone concentrations (ppbv) and climatic parameters (temperature, radiation, wind direction and speed) at Aix-en-Provence in the center of the domain during the field experiment.

composed of Mediterranean shrubs), which constitute a sampling of the cover in the ESCOMPTE area.

\subsubsection{Aerosol stations}

The physical and chemical properties of aerosol were measured at seven sites representative of urban, near urban, and rural areas. The aerosol size distribution was measured with a 
Scanning Mobility Particle Sizer (SMPS) and an optical counter. The chemical composition, including different ionic compounds, was deduced by chromatography analysis while black and organic carbon contents were deduced by thermal method. Aerosol optical properties were measured from a ground-based pyranometer complemented by aircraft measurements.

\subsubsection{Chemical stations}

The chemical stations were used to follow the pollutant plume and investigate its chemical time evolution in a 'lagrangian mode'. The 18 stations dedicated to chemical measurement were set into three groups with respect to their location compared to the two main anthropogenic emission sources (Marseilles, industrial site of Berre pond): emission sites, intermediate sites and remote sites. The location of these various sites is given in Appendix B. The best equipped stations were located along trajectories generally followed by the air masses during meteorological conditions investigated during the ESCOMPTE campaign. Three axes were instrumented by at least three stations located in the three sections (emission sites, intermediate sites, and remote sites).

This network of ground stations was complemented by two stations onboard of ships in order to obtain information on the chemical and meteorological conditions at the outskirts of the region under study, but also to obtain a better monitoring of atmospheric chemistry over the sea. The first was a commercial ship, which links Marseilles to Corsica. During the whole campaign, it gave information on $\mathrm{O}_{3}, \mathrm{NO}_{\mathrm{x}}$ and $\mathrm{SO}_{2}$ concentrations. The second was the scientific vessel from INSU (Téthys II) on which a specific instrumentation for atmospheric analysis was embarked. The location of the ship depended on the actual trajectories of the pollutant plumes. This ship was available from 2 to 13 of July.

\section{Campaign progress}

The main field campaign was carried out in the ESCOMPTE area from June 10 to July 13,2002 , just after a series of quality assurance testing experiments.

\subsection{Quality control and quality assurance (QC/QA)}

A large set of ground based, onboard and remote data was collected through several measurement techniques. For example, ozone was monitored using ground based point monitors, lidars, ECC sondes and airplanes. Reliability of such a database can be obtained by checking the coherence factor (dispersion of results) between different measuring techniques to be used for models parameterization and validation.

Quality controls were made preliminarily during the campaign itself from 5 to 10 of June at four sites. The gas and aerosol measurements were compared at Avignon airport and Realtor site, respectively, the remote sensing and the surface turbulent flux at Aix-les-Milles and over the La Crau plain, respectively. Moreover, specific flights (with planes flying in pairs) were carried out to compare aircraft measurements.

All gaseous monitors used in airplane, mobile laboratory, and air quality network, were calibrated by reference traceable gases $\left(\mathrm{NO}_{\mathrm{x}}, \mathrm{CO}\right)$, NIST standard $\mathrm{O}_{3}$ generators, and pressure and temperature standards. Specific recommendations were also proposed, related 
to the sampling line characteristics, the input filter of gaseous monitor and the data integration and treatment.

Due to a lack of knowledge on the uncertainty of each instrument, it was also decided to evaluate the global uncertainty associated to a measurement, by carrying out some intercomparisons. For example, all $\mathrm{O}_{3}$ point monitors revealed an experimental standard deviation below $15 \%$ level, but after post-processings and corrected span functions, the standard deviation went below to $8 \%$.

Such ozone intercomparison was also applied to all altitude ozone instruments, including five airplanes, five lidars, and instrumented balloons. This global intercomparison of all calibrated instruments, and having their individual uncertainty lower than $10 \%$ (de la Noë et al., 1987, Thomasson et al., 2002), had shown coherence between all results. This applies to qualitative description of the atmospheric ozone stratification, and quantitative evaluation (with scattering lower than $20 \%$ due to sampling conditions and non-exactly co-localized measurements). Minor discrepancies between results from some techniques were observed, which led to specify the limitations of each instrument as a function of parameter dependency (temperature or humidity). We can reasonably suppose that all ozone measurement techniques are within a confidence interval better than $10 \%$ in case of not so distant measurements (in time and space).

Specific quality control protocols were also developed for VOC (carbonyl compounds, NMHC), aerosol (black carbon, filter sampling), and $J_{\mathrm{NO}_{2}}$. For VOC measurements, which were performed using on-line, canister and active samplings, a calibration protocol was performed using NPL standard gases. Due to the lack of European guidelines and recommendations, and the lack of knowledge on major uncertainty components with each measuring method, it was decided to have an intercomparison period where all instruments will work in parallel. Further data processing will be made in order to evaluate the global uncertainty to the VOC measurement. The expected final confidence interval in VOC measurement were within $10-20 \%$ for most of the $\mathrm{C} 2-\mathrm{C} 8$ compounds (Apel et al., 1999; Plass-Dülmer et al., 2002; Slemr et al., 2002).

Turbulent fluxes intercomparison was carried out over the "La Crau" plain $\left(43^{\circ} 34^{\prime} \mathrm{N}\right.$, $04^{\circ} 49^{\prime} \mathrm{E}$ ). This site located in the western part of the ESCOMPTE domain is particularly suitable for this kind of exercise (flat area with homogeneous land cover, large fetch). The comparison took into account both measurements and treatment errors. Parameters, which have been compared, were:

- wind speed and direction, "sonic" temperature,

- variances of temperature and wind components,

- vertical velocity-temperature and vertical velocity-humidity covariances $\overline{w^{\prime} T^{\prime}}$ and $\overline{w^{\prime} q^{\prime}}$, and friction velocity $\mathrm{U}^{*}$.

Ten masts have been implemented on an area of about $10^{4} \mathrm{~m}^{2}$. Only one energy fluxes station was based on the simplified aerodynamic method, whereas the others provided fast measurements (between 10 and 20 points/s) to compute the fluxes with the eddycovariance method. Eleven sonic anemometers from five different manufacturers, one Licor Li 6262 and eight krypton KH20 hygrometers were implemented during this intercomparison. 
The scatter between the various platforms was between $10 \%$ and $20 \%$ during daytime for $\overline{w^{\prime} T^{\prime}}$ and $\mathrm{U}^{*} ; \overline{w^{\prime} q^{\prime}}$ estimates were more scattered $(20 \%$ to $40 \%$ during the same period), mainly due to the delicate calibration of the krypton.

\subsection{Field experiment}

\subsubsection{Alert and IOP setting-off}

Meteorological and air quality conditions were analyzed based upon air masses trajectories and different forecasting model output (meteorological and chemical). When favorable conditions were foreseen (typically a high altitude ridge over the area, as an extension of an anticyclone located over Southern Europe), decision was made to activate the IOP starting process according to the following protocol:

- pre-alert: (D - 2) day (D is the first IOP day).

- alert: (D - 1) day: balloons, radiosondes, and remote sensing teams sent on site. Confirmation of aircraft flights.

- early morning of D day: start of the IOP. During the first IOP day, only a few aircraft flights and CVB releases were performed, because it was considered as being the beginning of the pollution episode. However, the radiosondes were launched at a "normal IOP" rate, in order to be able to optimize the initial conditions, for future studies of the IOP.

This starting process could be stopped at any time until $(\mathrm{D}-1)$ at mid-day. This set up has proved to be efficient to start the IOPs at the proper time. Among the five IOPs documented no false alert was initiated, even if the first one did not truly characterize a polluting event.

\subsubsection{Overview of the intensive observations periods}

The period and the site of the ESCOMPTE campaign were particularly favorable to the pollution event studies (Fig. 9). In 1 month, no less than 11 days were affected by atmospheric pollution. In this context, we carried out five IOPs with different local meteorological conditions.

4.2.2.1. IOP1 (14-15/06/2001). These 2 days have to be considered as a test for the whole ESCOMPTE experimental set up. June 15 was well documented with eight aircraft flights, with cloudy conditions, a thin boundary layer, and low pollution levels.

4.2.2.2. IOP2 (21-26/2001). It was decided to share this IOP into two contiguous parts, called $2 \mathrm{a}$ and $2 \mathrm{~b}$, since meteorological conditions changed significantly on June 23 . The IOP changing time was fixed at 1700 UTC.

IOP $2 a(21-23 / 06 / 2001)$. The IOP2a period corresponds to the end of a Mistral situation with a moderate $\mathrm{NW}$ to $\mathrm{W}$ wind, clear skies, hot temperature $\left(>30{ }^{\circ} \mathrm{C}\right)$. Marseilles and Berre plumes extended towards the East and over the sea. Highest surface ozone concentrations were found around Toulon, in the most eastern part of the ESCOMPTE domain. Six and eight flights were performed on June 22 and 23, 


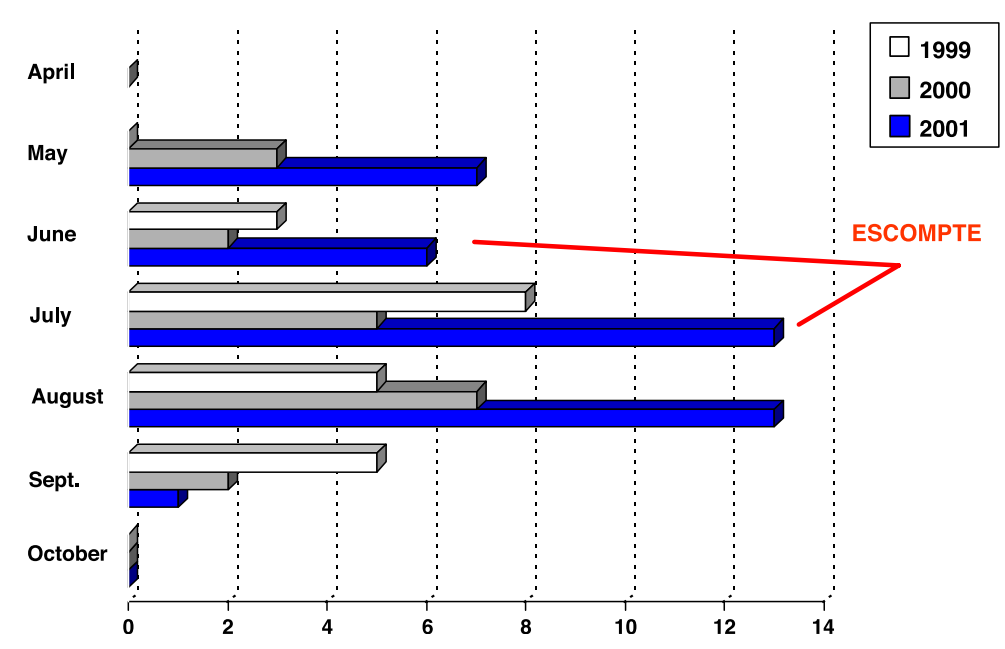

Fig. 9. Histogram of the ozone pollution events (number of days with the surface ozone concentration $>90 \mathrm{ppbv}$ during $1 \mathrm{~h}$ on two sites at least) on the ESCOMPTE domain in the year 2001 compared with previous years.

respectively, and six CVBs were released during this IOP, two of them (on June 21 and 22) equipped for ozone measurements.

IOP2b (23-26/06/2001). The IOP2b best characterizes a pollution event. During three windless days, temperature $\left(>34^{\circ} \mathrm{C}\right)$ and surface ozone concentration $(125 \mathrm{ppbv}$ all around Aix-en-Provence on June 24; 100 ppbv over the whole domain and up to $150 \mathrm{ppbv}$ in the Durance Valley on June 25; 115 ppbv in the Rhone valley on June 26 with a light southerly wind) reached high values. This episode was heavily documented with eight, eight, and nine flights performed on June 24, 25, and 26, respectively, and eight CVBs released, four of them with an ozone probe. Example of experimental and simulated ozone fields on June 24 at 1200 UTC is given in Fig. 10.

4.2.2.3. IOP3 (02-04/07/2001). A short but interesting episode was characterized by a sea breeze interacting with a synoptic S/SW flux. On the last day, the SW wind became stronger and cloudiness appeared on the domain. On 2, 3, and 4 of July, 6, 8 and 10 flights, respectively, were performed and $7 \mathrm{CVBs}$ were launched, 3 of them with an ozone probe. The data collected during this IOP, except operational ones, will be hidden for a period of time, in order to perform a blind model intercomparison exercise.

4.2.2.4. IOP4 (10-13/07/2001). The last IOP was launched under hot temperature and clear sky conditions but with a W/NW synoptic wind that prevented the accumulation

Fig. 10. Ozone field in the ESCOMPTE domain on June 24 at 1200 UTC obtained from (a) network measurements and a kriging interpolated model; (b) airborne measurements in the boundary layer; (c) simulation with the MOCAGE CTM. Meteorological 'forcings' are from Météo-France ALADIN model, with a horizontal resolution of approximately $10 \mathrm{~km}$. The ozone plume formed around Aix-en-Provence is seen by MOCAGE lightly shifted in the Marseilles area. 

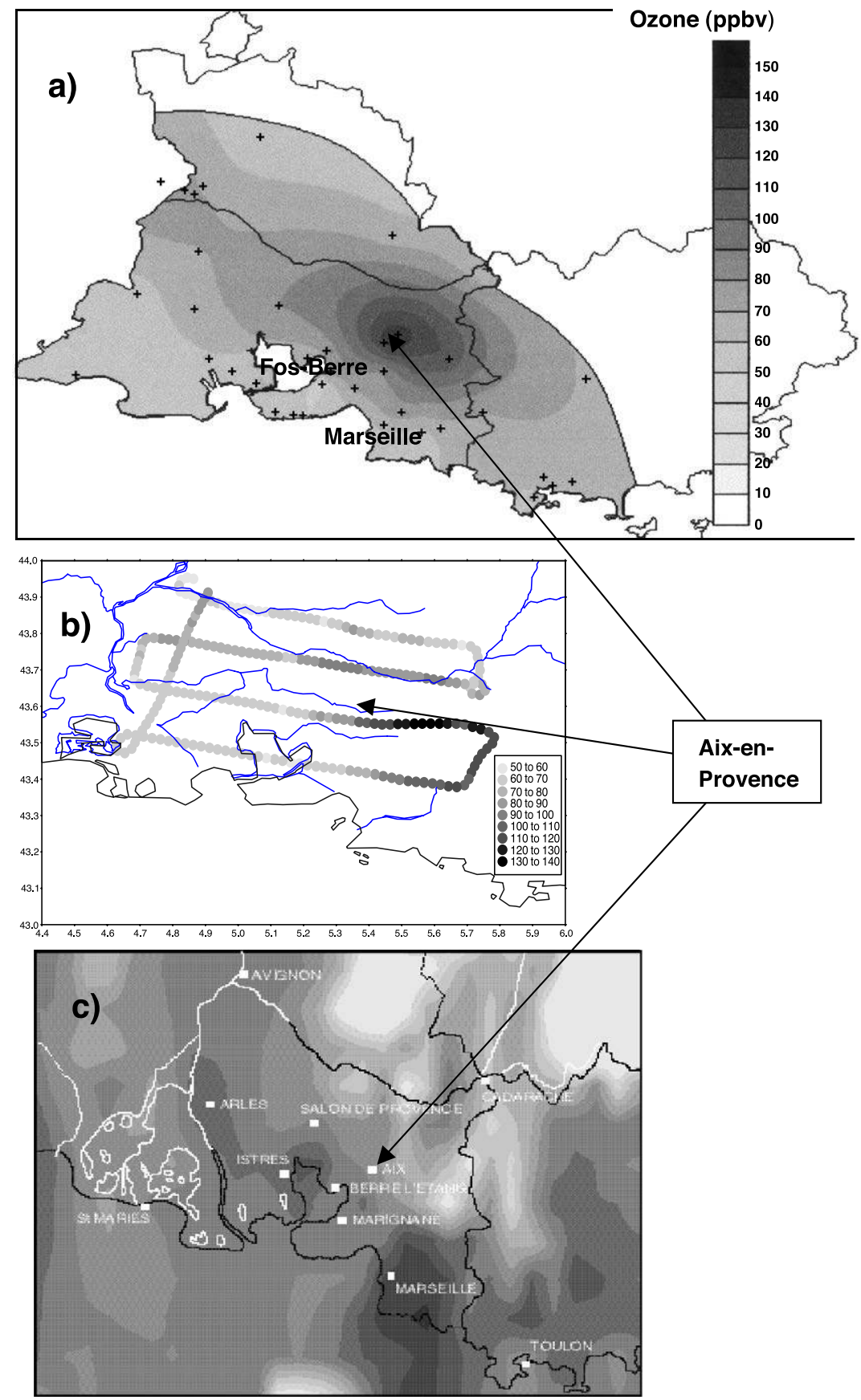
of pollutants. However, since photochemistry was active, this may have been a good situation for plume process studies. Four, five, six, and four flights were made on 10, $11,12,13$ of July, respectively, and nine CVBs were released, five of them with an ozone probe. A timetable of the 2001 campaign is presented in Fig. 11 for the airborne means (plane, CVB, RS).

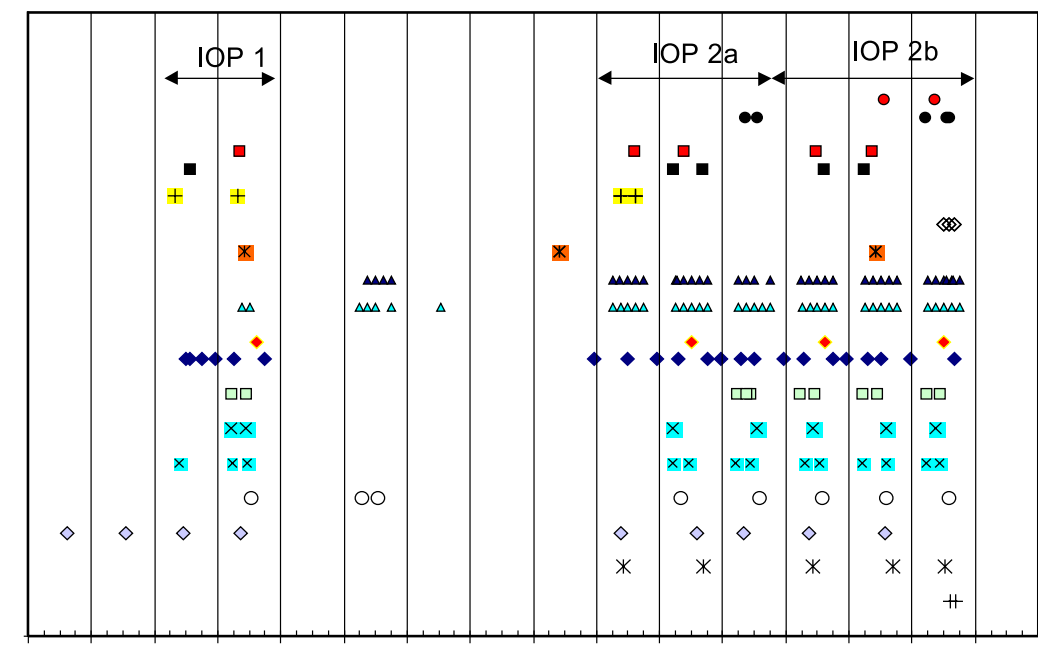

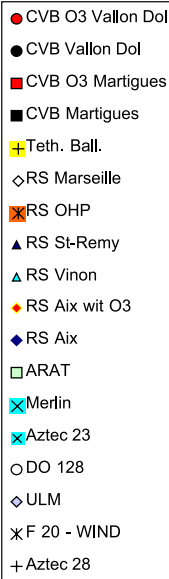

163164165166167168169170171172173174175176177178

Day of year

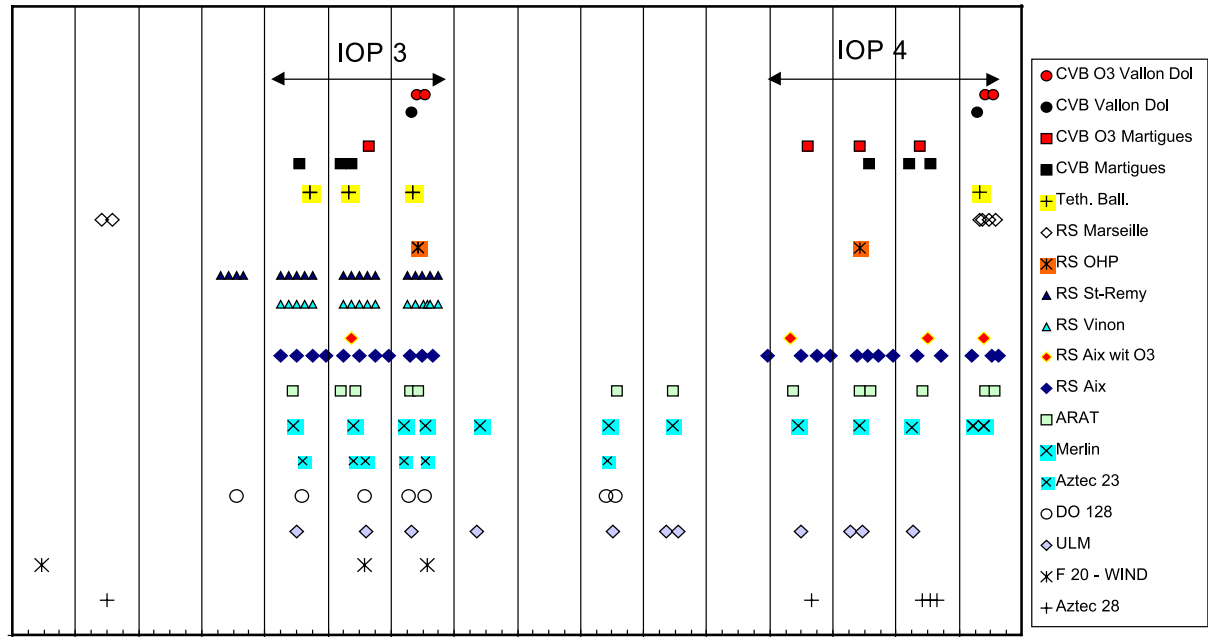

179180181182183184185186187188189190191192193194

Day of year

Fig. 11. Time table of the airborne means (plane, balloons, and radiosondes) during the ESCOMPTE campaign. 


\subsection{Preliminary results}

\subsubsection{Ozone plumes over the ESCOMPTE domain}

We will describe the situation observed during the IOP $2 b$ presented above. On June 24 the weather is sunny and warm. The temperatures reach $27{ }^{\circ} \mathrm{C}$ during afternoon. In the morning, we observe a NW wind over the continent and the development of a sea breeze over the Mediterranean shoreline. During the afternoon the wind field is rather complex. A SW sea breeze blows over the southern part of the domain whereas a residual wind enters by the north, both merge into a $\mathrm{W}$ wind in the eastern part. In the early morning, the residual layer shows very homogeneous ozone levels ranging from 50 to $70 \mathrm{ppbv}$. Around noon, $30 \mathrm{~km}$ inland downwind Marseilles, an ozone plume is clearly identified with ozone concentrations as high as $130 \mathrm{ppbv}$ (Fig. 12). Given the ozone concentration level observed during early morning, it appears that the local $\mathrm{O}_{3}$ production is a major contribution to the ozone plume concentration. We can also notice a small extension of this plume downwind the industrial area of Berre pond.

We observed the same behavior for $\mathrm{NO}_{\mathrm{x}}$ and $\mathrm{NO}_{\mathrm{y}}$ with the presence of a plume in the same area with concentrations reaching 4 and 6 ppbv, respectively.

\subsubsection{Aerosols during ESCOMPTE}

Fig. 13 presents a chemical closure of aerosols during ESCOMPTE IOP2b for the different aerosol sites. Aerosols mass concentration results allow to show the strength of
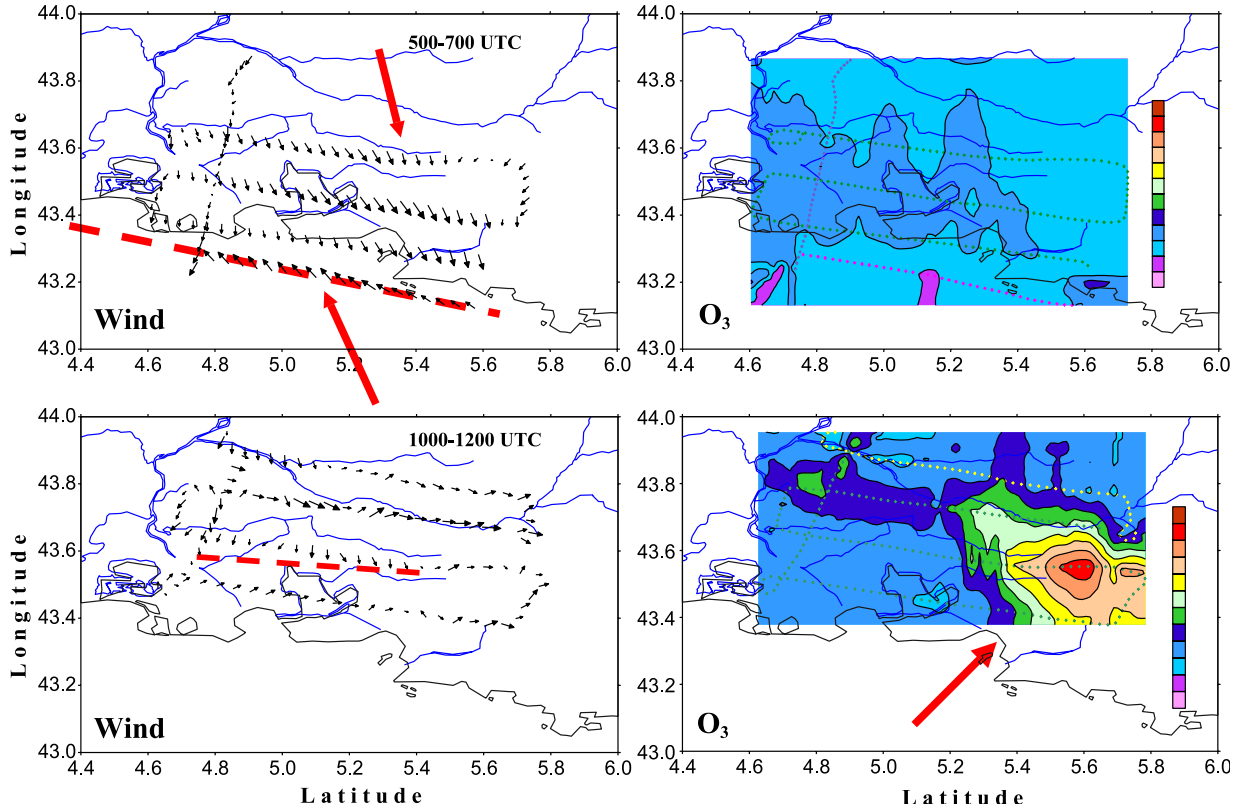

Fig. 12. Wind and ozone field from ARAT measurements on June 24 in the morning (0500-0700 UTC) and at noon (1000-1200 UTC). The red arrows indicate the prevailing winds and the dashed line the sea-breeze front. The color scale is for values in ppbv. 

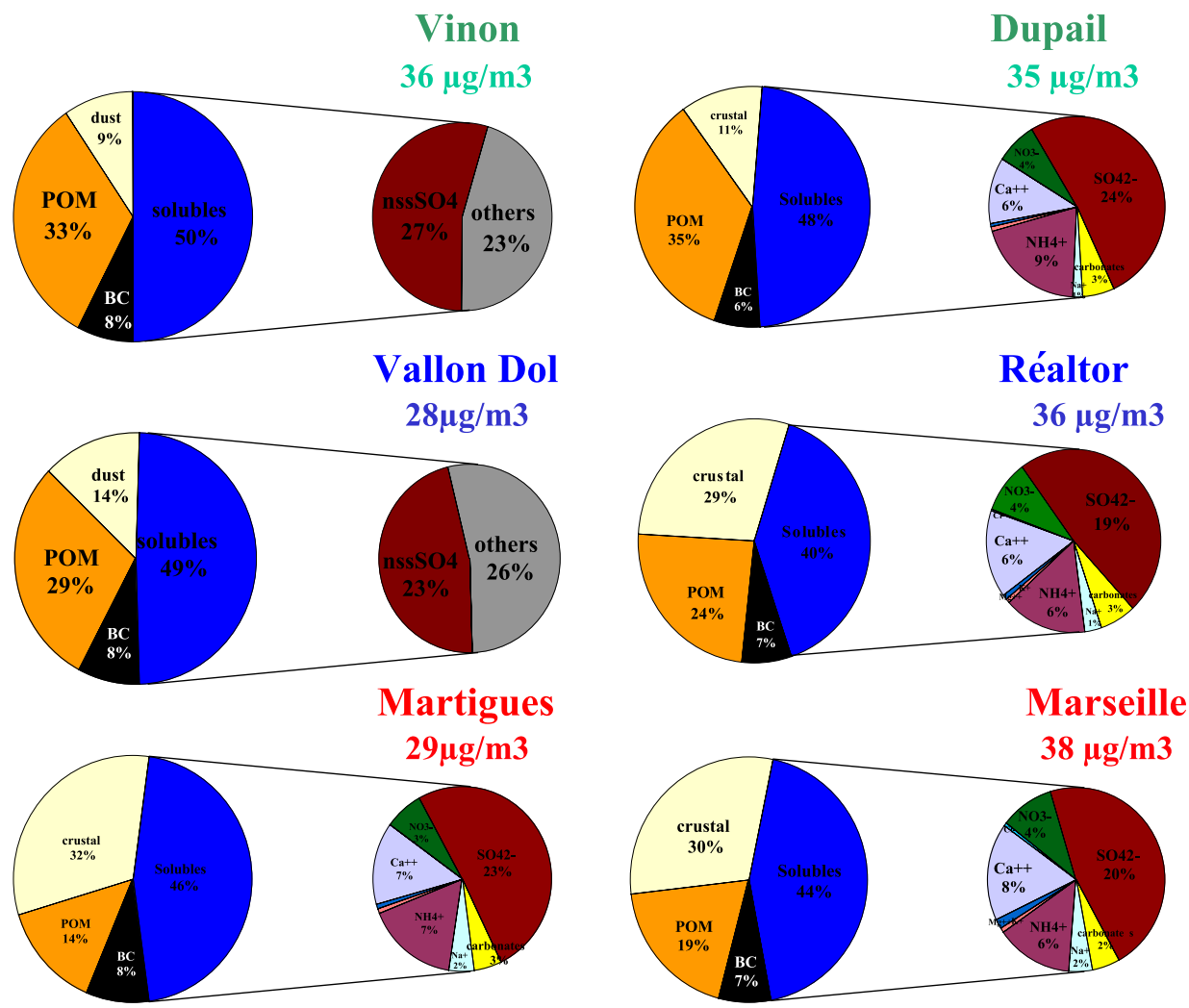

Fig. 13. Chemical closure of aerosols during ESCOMPTE IOP2b for the different aerosol sites (red: source, blue: peri-urban, green: remote). Crustal or dust is the unresolved fraction; POM is calculated from POC $(\times 1.4$ or 1.5$)$ and $\mathrm{CO}_{3}$ is calculated from ion balance.

the main prevailing sources. At each site (source or remote sites) many indicators point out the role of the intense secondary sources when radiation is high enough for photochemistry to occur.

The abundance of fine sulfate at source sites is noticeable and reveals the importance of $\mathrm{SO}_{2}$ conversion close to the sources (Martigues, Marseilles). Another striking feature is the abundance of carbonaceous particle $(\mathrm{POM}+\mathrm{BC})$ which always represents the major fraction of the aerosol.

At remote sites (Vinon, Dupail) the organic fraction is by far the most abundant component due to en-route conversion of VOCs emitted either by anthropogenic sources or by active vegetation. Such conversion could also play a significant role in the formation of ozone.

\subsubsection{The sea breeze}

The wind field was measured with the Franco-German airborne Doppler lidar WIND onboard the DLR-Falcon 20 (see Reitebuch et al., 2001, 2003 for more details). Fig. 14 

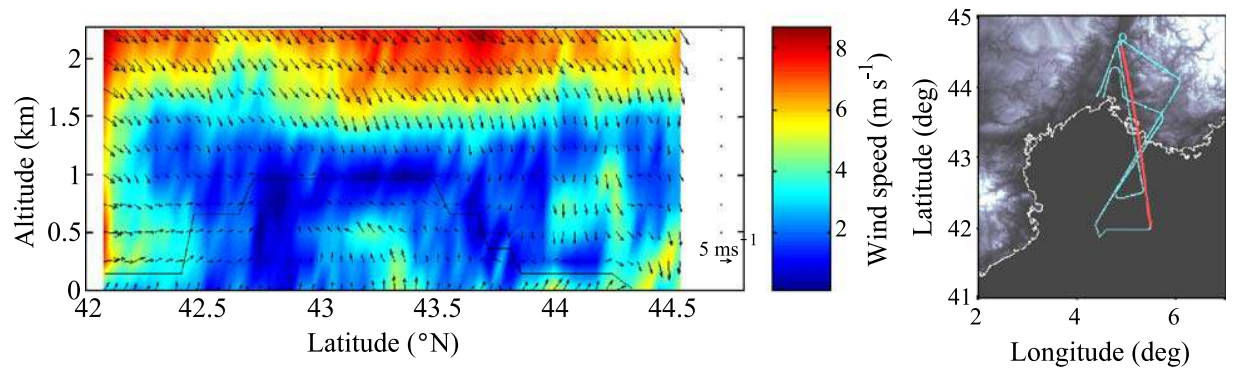

Fig. 14. Wind field retrieved with the Franco-German airborne Doppler lidar WIND onboard the DLR-Falcon 20 from $140 \mathrm{~km}$ offshore to $120 \mathrm{~km}$ onshore along the Rhone valley on June 252001 between 1644 and 1712 UTC. Arrows indicate the wind direction as a function of height and are scaled to fit within the wind strength (see also the color scale). The limits of the breeze cell are indicated. The icon on the right-hand side depicts the flight tracks where the plane flew during ESCOMPTE. The flight track of June 25 is in red.

displays the wind on 25 June 2001 between 1644 and 1712 UTC from $140 \mathrm{~km}$ offshore to $120 \mathrm{~km}$ onshore along the Rhone valley with a horizontal resolution of about $3 \mathrm{~km}$ and a vertical resolution of $250 \mathrm{~m}$. Arrows indicate the wind direction as a function of height and are scaled to fit within the wind strength (see also the color scale). One can see a weak southerly low-level flow $(0-4 \mathrm{~m} / \mathrm{s})$ below a stronger northwesterly flow channeled in the Rhone valley. The southerly flow is the well-developed sea breeze, which extends from $42^{\circ} \mathrm{N}$ to $44.2^{\circ} \mathrm{N}$ (visible sea-breeze front) and is about $1 \mathrm{~km}$ deep. As the breeze enters the Rhone valley $\left(\right.$ after $\left.44^{\circ} \mathrm{N}\right)$, it is accelerated probably due to a Venturi effect. One can also note the acceleration over the Berre pond may be due to weaker surface roughness. Another point that is worth being emphasized is the existence of flow splitting between the Rhone and Durance valleys (not shown). These topographical specificities are of great importance since coastal flow regimes take a prominent part in the pollution transport.

\section{Development of the program}

\subsection{The ESCOMPTE Data Base (EDB)}

The ESCOMPTE program has achieved a comprehensive and coherent database that is expected to allow the testing and evaluation of regional pollution models. This database, called ESCOMPTE database (EDB), is managed by Médias-France. There are three separate types of data:

(1) Data collected during the 2000 and 2001 campaigns by the partners, using additional and specific instrumentation. This type of data also includes data collected from associated programs GPS/H2O and UBL;

(2) Emission data, for the ESCOMPTE area;

(3) Data belonging to the public domain (meteorological data set, monitoring networks on air quality) and covering the period of the campaign; background data and information 
(description of meteorological and large-scale chemical environment, satellite data, orography, surface coverage...).

It is expected that some data sets might evolve, namely into:

- Type-1 data, when re-calibration or improved processing are made available;

- Type-2 data, when additional information on emissions from cars, factories, urban and rural environment will be fully collected for the period covering the 2001 campaign;

- Type-3 data, when improved output from large-scale chemistry models, becomes available.

\subsection{Data Base policy}

The overall policy is based on three leading principles: offer easy access to the EDB for the ESCOMPTE scientific community leading to scientific publication involving principal investigators (PIs); maintain easy access to the EDB in the future; maximize the use of the EDB in order to evaluate pollution models output. The EDB policy was defined in a document, which explains how to use the data collected during ESCOMPTE and can be consulted through the ESCOMPTE web site at the following address: http://medias.obs-mip.fr/escompte.

\subsection{Modeling strategy}

Modeling studies will focus on four main elements, evaluation and intercomparison of models; chemical, dynamic and thermodynamic process studies for gases and aerosol; study of vertical transport and distribution of pollutants; scale interactions and import/ export of pollutants. An international modeling exercise is programmed for 2003 to serve the first objective. For the three subsequent ones, model simulations will principally rely on the ESCOMPTE specific emissions inventory and on the quality-checked database.

\section{Summary and perspectives}

The data set gathered during the ESCOMPTE field phase undoubtedly constitutes a reference against which mesoscale CTMs could be compared in the forthcoming years. Although the principal effort at this time is devoted to completion and improvement of the EDB, several thematic studies have already been undertaken, among which the following can be mentioned:

- The data collected during the QC/QA operations, and more generally comparisons of same parameters measured by various instruments, should improve the measuring accuracy and reliability. This concerns ozone profiling (as measured by ground-based lidars, radiosondes, aircraft probes, and CVBs), wind profiling (as measured by Doppler sodars, radars and lidars (ground-based and airborne), and rawinsondes. Several studies will also be devoted to the retrieval of parameters to be deduced from 
the primary measurements. For example, the boundary-layer thickness from wind profilers (radars and lidars), turbulence characteristics from UHF radars, or mean vertical wind at various scales (from the local one, through a single wind profiler, to upper scales, from the profiler network over the domain).

- The high number of profilers (21 sodar/radar/lidar), the aircraft measurements and the rawinsondes should supply a thorough documentation of the various superposed layers in the lower troposphere. From the simultaneous analyses of wind, ozone, and aerosol, we expect to understand the origin and evolution of these various reservoirs or sinks of pollutants. These stacked layers are characteristic of this area, and probably result from the interaction of large-scale transport with local circulation like sea-lake breezes and terrain elevation constraints.

- The plumes are transported by the mean (horizontal and vertical) wind and diluted by turbulence from the two main emission areas (city of Marseilles and the Berre pond). Given the complex dynamic characteristics of the area, including sea and lake breezes across a tortuous shoreline, and highly varying terrain features (elevation, surface cover,...), a precise description of the flow has to be reached at various scales. This will include vertical exchanges (surface flux, transfer across the boundary-layer top, transport along slopes and within breeze fronts,...), horizontal dilution by turbulence, and channeling effects by hills and mountains. These studies will be correlated with the preceding issue through the description of the boundary-layer variability.

- The budget of pollutants, like ozone, results from the transport and diffusion, as mentioned above, and from the chemical transformations, including natural and anthropogenic primary pollutants. These studies will therefore deal with chemistry and radiation measurement/modeling. Improved deposition velocities, deduced from the ozone surface flux, but also emission/deposition of nitrogen compounds are required to better monitor the time-variation of the concentrations. The profiles continuously measured by several instruments during several days in the IOPs, combined with aircraft and balloon-borne measurements and modeling at various scales, would allow the establishment of a complete budget for some species of interest. This is probably one of the core actions of the program.

- As mentioned earlier, the achievement of the emissions inventory is a crucial challenge without which high quality modeling could not be performed. This constitutes one of the major effort during the period which followed the ESCOMPTE campaign.

\section{Acknowledgements}

In the framework of the French programs PNCA and PRIMEQUAL-PREDIT, ESCOMPTE was performed thanks to funding from the "Ministère de l'Ecologie et du Développement Durable (MEDD)", the "Agence de l'Environnement et de la Maîtrise de l'Energie (ADEME)", the "Institut National des Sciences de l'Univers (INSU)", MétéoFrance, the "Institut National de l'Environnement Industriel et des Risques (INERIS)", the German funding agency (BMBF), the Institute for Meteorology and Climate Research (IMK-Karlsruhe), the Joint Research Center (JRC-Ispra), the Swiss Federal Institute of 
Technology (EPFL-Lausanne), the"Centre National d'Etudes Spatiales (CNES)", "Electricité de France (EDF)", the air quality agencies AIRMARAIX and AIRFOBEP, the cities of Marseilles and Aix-en-Provence, and the county council of the Bouches-duRhône. We are also grateful to the "Société de Navigation Corse Méditerranée (SNCM)" for their help and assistance with sea measurements.

We express our sincere appreciation to S. Joussaume and C. Elichegaray for their coordination effort and support before, during and after the field experiment, and to J.P. Lacaux who permitted to solve customs clearance problems.

We particularly thank M.P. Lefebvre who played a crucial role in the delicate organization of the flights, J.F. Mauro who organized the ground-based sites, F. Marin our scientific secretary, and all the people involved in the performance of the field campaign, whose commitment ensured the success of this operation. Thanks are extended to the reviewers for their helpful comments and to Y. M. Tourre for helping us with the English version of the manuscript.

\section{Appendix A}

Principal investigators in the ESCOMPTE (and associated) field experiment

\begin{tabular}{|c|c|c|}
\hline Investigator & Institution & Investigation \\
\hline Allet Christian & DT, INSU, Meudon & ARAT measurements \\
\hline Ancellet Gérard & SA, IPSL, Paris & Lidar: ozone, aerosols \\
\hline Bénech Bruno & LA/CRA, OMP, Lannemezan & CVB: lagrangian measurements \\
\hline Blake Donald & UCI, Irvine & VOC \\
\hline Bock Olivier & SA, IPSL, Paris & $\mathrm{GPS} / \mathrm{H}_{2} \mathrm{O}$ \\
\hline Caccia Jean Luc & LSEET, Toulon & Radar: wind field \\
\hline Cachier Hélène & LSCE, Gif/Yvette & Aerosol \\
\hline Calpini Bertrand & EPFL, Lausanne & Lidar measurements \\
\hline Campistron Bernard & LA/CRA, Lannemezan & Tethered balloon \\
\hline Cautenet Sylvie & LaMP, Clermont-Ferrand & Modeling \\
\hline Coll Isabelle & LISA, Créteil & Modeling \\
\hline Corsmeier Ulrich & IMK Karlsruhe & Dornier 128 aircraft \\
\hline Cros Bernard & LA, OMP, Toulouse & Ozone \\
\hline Cuvelier Kees & JRC, Ispra & Modeling \\
\hline Dabas Alain & CNRM, Météo-France, Toulouse & Doppler lidar WIND \\
\hline Delbarre Hervé & UCLO, Dunkerque & Ozone scanning lidar \\
\hline Despiau Serge & LEPI, Toulon & Aerosol \\
\hline Doerflinger Erik & LGTS, Montpellier & $\mathrm{GPS} / \mathrm{H}_{2} \mathrm{O}$ \\
\hline Drobinski Philippe & LMD, Palaiseau & Lidar: dynamics measurements \\
\hline Dupont Eric & EDF, Chatou & Radar, sodar: wind field \\
\hline Durand Pierre & CNRM, Météo-France, Toulouse & Dynamics measurements \\
\hline Fréjafon Emeric & INERIS, Verneuil & Lidar: ozone, aerosols \\
\hline Gizard Emmanuel & CNRM, Météo-France, Toulouse & Wind profilers, RS, flux \\
\hline Grimmond Sue & Indiana University, Bloomington & Flux \\
\hline Jambert Corinne & LISA, Créteil & Sea measurements (Téthys II) \\
\hline Junkermann Wolfgang & IFU, Garmisch & Airborne meas ${ }^{\text {ts }}$ : ozone, aerosol \\
\hline Kalthoff Norbert & IMK, Karlsruhe & Sodar, RS, flux measurements \\
\hline
\end{tabular}


Appendix A (continued)

\begin{tabular}{|c|c|c|}
\hline Investigator & Institution & Investigation \\
\hline Klaus Vadislav & CNRM, Météo-France, Toulouse & VHF radar \\
\hline Kottmeier Christoph & IMK, Karlsruhe & Airborne meas ${ }^{\text {ts. }}$ dynamics-chemistry \\
\hline Laj Paolo & LaMP, Clermont-Ferrand & Aerosol \\
\hline Laverdet Gérard & LCSR, Orléans & Radicals \\
\hline Laville Patricia & INRA, Grignon & NOx emissions \\
\hline Lefebvre Marie-Pierre & CNRM, Météo-France, Brétigny & Flight coordinator \\
\hline Locoge Nadine & EMD, Douai & VOC \\
\hline Lopez Alain & LA, OMP, Toulouse & Flux measurements \\
\hline Masclet Pierre & TEPE, Chambéry & Aerosol \\
\hline Menut Laurent & LISA, Créteil & Modeling \\
\hline Mestayer Patrice & ECN, Nantes & BLU \\
\hline Moëller Detlev & BTU, Cottbus & Lidar and chemical measurements \\
\hline Oke Tim & Univ. of Brit. Columbia & Flux measurements \\
\hline Perros Pascal & LISA, Créteil & $\mathrm{NO}_{\mathrm{x}}$ and ozone \\
\hline Peuch Vincent-Henri & CNRM, Météo-France, Toulouse & Modeling \\
\hline Putaud Jean-Philippe & JRC, Ispra & Aerosol \\
\hline Reitebuch Oliver & DLR, Oberpfaffenhofen & Falcon 20 measurements \\
\hline Robin Dominique & AIRMARAIX, Marseille & Networks: ozone \\
\hline Rosset Robert & LA, OMP, Toulouse & Modeling \\
\hline Saïd Frédérique & LA, OMP, Toulouse & Airborne measurements \\
\hline Serça Dominique & LA, OMP, Toulouse & Sea measurements \\
\hline Simon Valérie & ENSIACET, Toulouse & VOC \\
\hline Sol Bernard & DIRSE, Météo-France, Aix & Meteorology \\
\hline Van Dingenen Rita & JRC, Ispra & Aerosol: airborne measurements \\
\hline Wortham Henri & LCE, Marseille & VOC \\
\hline Zephoris Marcel & DSO, Météo-France, Trappes & Ozone, radiation \\
\hline
\end{tabular}

\section{Appendix B}

Location of the ground-based stations with investigators in charge, parameters measured and/or instrument used. The sea sites are identified by $\mathrm{M}$, the inland sites by $\mathrm{E}$ near the emissions areas, $\mathrm{R}$ in rural areas, $\mathrm{I}$ between $\mathrm{E}$ and $\mathrm{R}$.

\begin{tabular}{|c|c|c|c|c|c|c|}
\hline Station & Site & Code & Location & $\begin{array}{l}\text { Parameters and/ } \\
\text { or instruments }\end{array}$ & $\begin{array}{l}\text { Investigators } \\
\text { in charge }\end{array}$ & $\begin{array}{l}\text { Laboratories } \\
\text { involved }\end{array}$ \\
\hline 1 & $\begin{array}{l}\text { Scientific } \\
\text { ship of INSU } \\
\text { (Thétys II) }\end{array}$ & M1 & $\begin{array}{l}\text { Mediterranean } \\
\text { sea }\end{array}$ & $\begin{array}{l}\mathrm{O}_{3}, \mathrm{NO} / \mathrm{NO}_{2}, \\
\mathrm{NO}_{\mathrm{y}}, \mathrm{PAN}, \\
\mathrm{COV}, \mathrm{CO}, \\
\mathrm{RCHO}, J_{\mathrm{NO}_{2}}\end{array}$ & C. Jambert & LISA, LCE \\
\hline 2 & Ferry SNCM & M2 & & $\begin{array}{l}\mathrm{O}_{3}, \mathrm{NO} / \mathrm{NO}_{2}, \\
\mathrm{SO}_{2}\end{array}$ & D. Serça & LA \\
\hline \multirow[t]{2}{*}{3} & $\begin{array}{l}\text { Prado Saint } \\
\text { Sébastien }\end{array}$ & E1 & $\begin{array}{l}43^{\circ} 16^{\prime} \mathrm{N} / \\
5^{\circ} 23^{\prime} \mathrm{E}\end{array}$ & $\begin{array}{l}\mathrm{O}_{3}, \mathrm{NO} / \mathrm{NO}_{2}, \\
\mathrm{COV}, \mathrm{CO}, \\
\mathrm{RCHO}\end{array}$ & D. Robin & $\begin{array}{l}\text { Airmaraix, } \\
\text { UCI, LCE }\end{array}$ \\
\hline & & & & $\begin{array}{l}\text { Aerosol, optical } \\
\text { thickness }\end{array}$ & & LEPI, LOA \\
\hline
\end{tabular}


Appendix B (continued)

\begin{tabular}{|c|c|c|c|c|c|c|}
\hline Station & Site & Code & Location & $\begin{array}{l}\text { Parameters and/ } \\
\text { or instruments }\end{array}$ & $\begin{array}{l}\text { Investigators } \\
\text { in charge }\end{array}$ & $\begin{array}{l}\text { Laboratories } \\
\text { involved }\end{array}$ \\
\hline 4 & Martigues & E2 & $\begin{array}{l}43^{\circ} 25^{\prime} \mathrm{N} / \\
5^{\circ} 03^{\prime} \mathrm{E}\end{array}$ & $\begin{array}{l}\mathrm{O}_{3}, \mathrm{NO} / \mathrm{NO}_{2}, \mathrm{CO} \\
\text { Aerosol } \\
\text { CVB } \\
\text { (launching site) }\end{array}$ & $\begin{array}{l}\text { A. Léopold } \\
\text { B. Dartiguelongue }\end{array}$ & $\begin{array}{l}\text { Airfobep } \\
\text { LSCE } \\
\text { LA, CNES }\end{array}$ \\
\hline 5 & Realtor & E3 & $\begin{array}{l}43^{\circ} 29^{\prime} \mathrm{N} / \\
5^{\circ} 20^{\prime} \mathrm{E}\end{array}$ & $\begin{array}{l}\mathrm{O}_{3}, \mathrm{NO} / \mathrm{NO}_{2}, \\
\mathrm{NO}_{y}, \mathrm{COV}, \\
\mathrm{CO}, \mathrm{RCHO}, \\
\mathrm{H}_{2} \mathrm{O}_{2}, J_{\mathrm{NO}_{2}} \\
\text { Lidar } \mathrm{O}_{3} \\
\text { Aerosol, optical } \\
\text { thickness } \\
\text { Met station }\end{array}$ & $\begin{array}{l}\text { H. Wortham } \\
\text { H. Cachier }\end{array}$ & $\begin{array}{l}\text { BTU } \\
\text { LSCE, LOA }\end{array}$ \\
\hline 6 & St. Chamas & E4 & $\begin{array}{l}43^{\circ} 32^{\prime} \mathrm{N} / \\
5^{\circ} 04^{\prime} \mathrm{E}\end{array}$ & $\begin{array}{l}\mathrm{O}_{3}, \mathrm{NO} / \mathrm{NO}_{2}, \\
\mathrm{HNO}_{3}, \mathrm{CO} \\
\text { Lidar } \mathrm{O}_{3}, \\
\text { DOAS } \\
\text { SODAR, flux, } \\
\text { RASS, UHF } \\
\text { Met station }\end{array}$ & E. Dupont & EPFL \\
\hline 7 & L'Estaque & E5 & $\begin{array}{l}43^{\circ} 22^{\prime} \mathrm{N} / \\
5^{\circ} 04^{\prime} \mathrm{E}\end{array}$ & $\begin{array}{l}\mathrm{O}_{3}, \mathrm{NO} / \mathrm{NO}_{2} \\
\mathrm{COV}\end{array}$ & S. Mathiot & $\begin{array}{l}\text { Airfobep } \\
\text { EMD }\end{array}$ \\
\hline 8 & Vallon Dol & E6 & $\begin{array}{l}43^{\circ} 21^{\prime} \mathrm{N} / \\
5^{\circ} 24^{\prime} \mathrm{E}\end{array}$ & $\begin{array}{l}\mathrm{O}_{3}, \mathrm{NO} / \mathrm{NO}_{2}, \\
\mathrm{NOy}, \mathrm{COV}, \mathrm{CO} \\
\text { Aerosol } \\
\text { Angular lidar } \mathrm{O}_{3} \\
\text { Angular } \\
\text { Doppler lidar }\end{array}$ & $\begin{array}{l}\text { P. Dobrinski } \\
\text { J.P. Putaud }\end{array}$ & $\begin{array}{l}\text { Ineris } \\
\text { LMD }\end{array}$ \\
\hline & & & & $\begin{array}{l}\text { CVB } \\
\text { (launching site) }\end{array}$ & B. Dartiguelongue & CNES, LA \\
\hline & & & & $\begin{array}{l}\mu \text { wave } \\
\text { radiometer (2) } \\
\text { solar }\end{array}$ & & ETHZ \\
\hline & & & & $\begin{array}{l}\text { spectrometer (2) } \\
\text { Sodar+RASS }(1)\end{array}$ & & Alliance Tech. \\
\hline & & & & Met station & & CNRM \\
\hline 9 & St Jérôme (1) & E7 & $\begin{array}{l}43^{\circ} 20^{\prime} \mathrm{N} / \\
5^{\circ} 25^{\prime} \mathrm{E}\end{array}$ & $\begin{array}{l}\text { Sodar, flux, } \\
\text { Met station }\end{array}$ & J.M. Rosant & $\mathrm{ECN}$ \\
\hline 10 & $\begin{array}{l}\text { Marseille } \\
\text { GLM (1) }\end{array}$ & E8 & $\begin{array}{l}43^{\circ} 15^{\prime} \mathrm{N} / \\
5^{\circ} 24^{\prime} \mathrm{E}\end{array}$ & $\begin{array}{l}\text { Sodar, flux, } \\
\text { Met station }\end{array}$ & A. Coppalle & CORIA \\
\hline 11 & $\begin{array}{l}\text { Marseille- } \\
\text { Observatoire }\end{array}$ & E9 & $\begin{array}{l}43^{\circ} 18 \mathrm{~N} / \\
5^{\circ} 24^{\prime} \mathrm{E}\end{array}$ & $\begin{array}{l}\text { Tethered balloon, } \\
\text { flux, Met station } \\
\text { Radiosonde, } \\
\text { UHF radar }\end{array}$ & F. Lohou & $\begin{array}{l}\text { LA CNRM, } \\
\text { LA } \\
\text { CNRM }\end{array}$ \\
\hline 12 & $\begin{array}{l}\text { Marseille-Cour } \\
\text { d'Appel }\end{array}$ & E10 & $\begin{array}{l}43^{\circ} 18^{\prime} \mathrm{N} / \\
5^{\circ} 24^{\prime} \mathrm{E}\end{array}$ & $\begin{array}{l}\text { Flux, Met station } \\
\text { Radiometers (1) } \\
\text { Scintillometer (1) }\end{array}$ & J. Noilhan & $\begin{array}{l}\text { IU, UBC } \\
\text { UBC, Ontario } \\
\text { INRA Bdx }\end{array}$ \\
\hline 13 & Marignane & E11 & $\begin{array}{l}43^{\circ} 26^{\prime} \mathrm{N} / \\
5^{\circ} 14^{\prime} \mathrm{E}\end{array}$ & UHF & M. Mauprivez & DSO \\
\hline
\end{tabular}


Appendix B (continued)

\begin{tabular}{|c|c|c|c|c|c|c|}
\hline Station & Site & Code & Location & $\begin{array}{l}\text { Parameters and/ } \\
\text { or instruments }\end{array}$ & $\begin{array}{l}\text { Investigators } \\
\text { in charge }\end{array}$ & $\begin{array}{l}\text { Laboratories } \\
\text { involved }\end{array}$ \\
\hline 14 & Istres & E12 & $\begin{array}{l}43^{\circ} 30^{\prime} \mathrm{N} / \\
4^{\circ} 56^{\prime} \mathrm{E}\end{array}$ & $\begin{array}{l}\text { Sodar, } \\
\text { VHF-RASS }\end{array}$ & R. Durbe & CNRM \\
\hline 15 & Marseille-Univ. & E13 & & Optical thickness & P. Perros & LISA \\
\hline 16 & $\begin{array}{l}\text { Net }(T, R H) \\
(20 \text { sensors })(1)\end{array}$ & E14 & Marseille city & $\begin{array}{l}\text { Temperature-- } \\
\text { humidity }\end{array}$ & G. Pigeon & CNRM \\
\hline 17 & $\begin{array}{l}\text { Net GPS } \\
\text { (16 receivers) (2) }\end{array}$ & E15 & Marseille City & IWV & E. Doerflinger & $\begin{array}{l}\text { IGN,LGTS, } \\
\text { SA, CNRM }\end{array}$ \\
\hline 18 & Plan d'Aups & I1 & $\begin{array}{l}43^{\circ} 20^{\prime} \mathrm{N} / \\
5^{\circ} 43^{\prime} \mathrm{E}\end{array}$ & $\begin{array}{l}\mathrm{O}_{3}, \mathrm{CO} \mathrm{HNO}_{3}, \\
\text { aerosol }\end{array}$ & P. Laj & $\begin{array}{l}\text { Airmaraix } \\
\text { LaMP, JRC }\end{array}$ \\
\hline 19 & Dupail & $\mathrm{I} 2$ & $\begin{array}{l}43^{\circ} 37^{\prime} \mathrm{N} / \\
5^{\circ} 24^{\prime} \mathrm{E}\end{array}$ & $\begin{array}{l}\mathrm{O}_{3}, \mathrm{NO} / \mathrm{NO}_{2}, \\
\mathrm{NO}_{\mathrm{y}}, \mathrm{COV}, \mathrm{CO}, \\
\mathrm{H}_{2} \mathrm{O}_{2}, \mathrm{RCHO}, \\
\mathrm{RO}_{2} \text {, aerosol } \\
\text { Met station }\end{array}$ & P. Masclet & $\begin{array}{l}\text { LCSR, UCI, } \\
\text { LCE } \\
\text { TEPE } \\
\text { CNRM }\end{array}$ \\
\hline 20 & Meyrargues & $\mathrm{I} 3$ & $\begin{array}{l}43^{\circ} 39^{\prime} \mathrm{N} / \\
5^{\circ} 32^{\prime} \mathrm{E}\end{array}$ & $\begin{array}{l}\mathrm{O}_{3}, \mathrm{NO} / \mathrm{NO}_{2} \\
\text { flux, Met } \\
\text { station, } \\
\text { emissions/ } \\
\text { deposition }\end{array}$ & P. Laville & $\begin{array}{l}\text { INRA, LA, } \\
\text { INRA, } \\
\text { CNRM }\end{array}$ \\
\hline 21 & La Crau & I4 & $\begin{array}{l}43^{\circ} 34^{\prime} \mathrm{N} / \\
4^{\circ} 49^{\prime} \mathrm{E}\end{array}$ & $\begin{array}{l}\mathrm{O}_{3}, \mathrm{NO} / \mathrm{NO}_{2} \\
\text { flux, Met } \\
\text { station, } \\
\text { emissions/ } \\
\text { deposition }\end{array}$ & $\begin{array}{l}\text { D. Serça } \\
\text { E. Gizard }\end{array}$ & $\begin{array}{l}\text { LA } \\
\text { CNRM, LA }\end{array}$ \\
\hline 22 & Bimont & I5 & $\begin{array}{l}43^{\circ} 30^{\prime} \mathrm{N} / \\
5^{\circ} 37^{\prime} \mathrm{E}\end{array}$ & $\begin{array}{l}\mathrm{O}_{3}, \mathrm{NO} / \mathrm{NO}_{2} \\
\mathrm{CO}\end{array}$ & D. Robin & Airfobep \\
\hline 23 & La Barben & I6 & $\begin{array}{l}43^{\circ} 37^{\prime} \mathrm{N} / \\
5^{\circ} 12^{\prime} \mathrm{E}\end{array}$ & $\begin{array}{l}\mathrm{O}_{3}, \mathrm{NO} / \mathrm{NO}_{2}, \\
\mathrm{CO}, \mathrm{SO}_{2}, \mathrm{COV} \\
\text { Flux } \\
\text { Met station } \\
\text { Emissions/ } \\
\text { deposition }\end{array}$ & D. Serça & $\begin{array}{l}\text { LA, LCEE, } \\
\text { CNRM }\end{array}$ \\
\hline 24 & $\begin{array}{l}\text { La Ste } \\
\text { Baume }\end{array}$ & I7 & $\begin{array}{l}43^{\circ} 19^{\prime} \mathrm{N} / \\
5^{\circ} 44^{\prime} \mathrm{E}\end{array}$ & $\begin{array}{l}\text { CVB } \\
\text { (tracking site) }\end{array}$ & M. Lothon & LA \\
\hline 25 & Aix-les-Milles & I8 & $\begin{array}{l}43^{\circ} 30^{\prime} \mathrm{N} / \\
5^{\circ} 22^{\prime} \mathrm{E}\end{array}$ & $\begin{array}{l}\mathrm{H}_{2} \mathrm{O} \text { lidar } \\
\mathrm{O}_{3} \text { lidar } \\
\text { UHF radar } \\
\text { Mini VHF radar } \\
\text { Radiosonde } \\
\text { (with } \mathrm{O}_{3} \text { ) }\end{array}$ & $\begin{array}{l}\text { J.L. Caccia/ } \\
\text { C. Hanuise }\end{array}$ & $\begin{array}{l}\text { SA, IGN } \\
\text { SA } \\
\text { Degreane } \\
\text { LSEET } \\
\text { CNRM }\end{array}$ \\
\hline \multirow[t]{2}{*}{26} & $\begin{array}{l}\text { Vinon/ } \\
\text { Cadarache }\end{array}$ & R1 & $\begin{array}{l}\text { Vinon: } \\
43^{\circ} 44^{\prime} \mathrm{N} / \\
5^{\circ} 47^{\prime} \mathrm{E}\end{array}$ & $\begin{array}{l}\mathrm{O}_{3}, \mathrm{NO} / \mathrm{NO}_{2} \\
\mathrm{HNO}_{3}, \mathrm{PAN}, \\
\mathrm{COV}, \mathrm{CO} \\
\mathrm{H}_{2} \mathrm{O}_{2}, \mathrm{RCHO}\end{array}$ & D. Robin & $\begin{array}{l}\text { IMK, JRC, } \\
\text { LCE, UCI }\end{array}$ \\
\hline & & & $\begin{array}{l}\text { Cadarache: } \\
43^{\circ} 42^{\prime} \mathrm{N} / \\
5^{\circ} 45^{\prime} \mathrm{E}\end{array}$ & $\begin{array}{l}\text { Flux, Met } \\
\text { station, sodar }\end{array}$ & & IMK \\
\hline
\end{tabular}


Appendix B (continued)

\begin{tabular}{|c|c|c|c|c|c|c|}
\hline Station & Site & Code & Location & $\begin{array}{l}\text { Parameters and/ } \\
\text { or instruments }\end{array}$ & $\begin{array}{l}\text { Investigators } \\
\text { in charge }\end{array}$ & $\begin{array}{l}\text { Laboratories } \\
\text { involved }\end{array}$ \\
\hline 26 & Vinon/Cadarache & $\mathrm{R}_{1}$ & $\begin{array}{l}\text { Cadarache: } \\
43^{\circ} 42^{\prime} \mathrm{N} / \\
5^{\circ} 45^{\prime} \mathrm{E}\end{array}$ & $\begin{array}{l}\text { Radiosonde } \\
\mathrm{O}_{3} \text { lidar } \\
\text { Aerosol } \\
\text { Optical } \\
\text { thickness }\end{array}$ & D. Robin & $\begin{array}{l}\text { Ineris } \\
\text { JRC } \\
\text { LOA }\end{array}$ \\
\hline 27 & Montmeyan & $\mathrm{R} 2$ & $\begin{array}{l}43^{\circ} 39^{\prime} \mathrm{N} / \\
6^{\circ} 06^{\prime} \mathrm{E}\end{array}$ & $\begin{array}{l}\mathrm{O}_{3}, \mathrm{NO} / \mathrm{NO}_{2} \\
\mathrm{SO}_{2}, \mathrm{COV} \\
\mathrm{CO}, \mathrm{Met} \\
\text { station, flux }\end{array}$ & D. Serça & $\begin{array}{l}\text { LA, LCEE } \\
\text { LA, CNRM }\end{array}$ \\
\hline 28 & Alpilles & R3 & $\begin{array}{l}43^{\circ} 46^{\prime} \mathrm{N} / \\
4^{\circ} 51^{\prime} \mathrm{E}\end{array}$ & $\begin{array}{l}\mathrm{O}_{3}, \mathrm{NO} / \mathrm{NO}_{2}, \\
\mathrm{NO}_{\mathrm{y}}, \mathrm{SO}_{2}, \mathrm{PAN}, \\
\mathrm{COV}, \mathrm{CO}, J_{\mathrm{NO}_{2}} \\
\text { Met station }\end{array}$ & C. Jambert & $\begin{array}{l}\text { LISA, } \\
\text { GRECA }\end{array}$ \\
\hline 29 & Petit Lubéron & R4 & $\begin{array}{l}43^{\circ} 48^{\prime} \mathrm{N} / \\
5^{\circ} 9^{\prime} \mathrm{E}\end{array}$ & $\begin{array}{l}\mathrm{O}_{3}, \text { radiation, } \\
\text { modified } \\
\text { Ceilometer }\end{array}$ & M. Zéphoris & DSO, LCEE \\
\hline 30 & Lubéron & R5 & $43^{\circ} 49^{\prime} \mathrm{N} /$ & $\begin{array}{l}\mathrm{O}_{3} \\
\mathrm{CVB} \text { (tracking site) }\end{array}$ & B. Bénech & $\begin{array}{l}\text { Airfobep } \\
\text { LA }\end{array}$ \\
\hline 31 & Carpentras & R6 & $\begin{array}{l}5^{\circ} 28^{\prime} \mathrm{E} \\
44^{\circ} 05^{\prime} \mathrm{N} / \\
5^{\circ} 03^{\prime} \mathrm{E}\end{array}$ & Spectroradiometer & M. Zéphoris & DSO \\
\hline 32 & Montmirail & R7 & $\begin{array}{l}44^{\circ} 10^{\prime} \mathrm{N} / \\
5^{\circ} 04^{\prime} \mathrm{E}\end{array}$ & $\mathrm{O}_{3}$ & M. Zéphoris & DSO \\
\hline 33 & Mont Ventoux & R8 & $\begin{array}{l}44^{\circ} 10^{\prime} \mathrm{N} / \\
5^{\circ} 17^{\prime} \mathrm{E}\end{array}$ & Met station & M. Zéphoris & DSO \\
\hline 34 & $\begin{array}{l}\text { St Rémy-de- } \\
\text { Provence }\end{array}$ & R9 & $\begin{array}{l}43^{\circ} 46^{\prime} \mathrm{N} / \\
4^{\circ} 54^{\prime} \mathrm{E}\end{array}$ & Radiosonde & C. Kottmeier & IMK \\
\hline 35 & Avignon & R10 & $\begin{array}{l}43^{\circ} 54^{\prime} \mathrm{N} / \\
4^{\circ} 54^{\prime} \mathrm{E} \\
37 \mathrm{~m}\end{array}$ & $\begin{array}{l}\text { Sodar, } \\
\text { optical thickness, } \\
\text { airplanes } \\
\text { Airplane data } \\
\text { processing }\end{array}$ & M.P. Lefebvre & $\begin{array}{l}\text { CAM, IMK, } \\
\text { IFU, INSU }\end{array}$ \\
\hline 36 & Toulon & R11 & $\begin{array}{l}43^{\circ} 12^{\prime} \mathrm{N} / \\
5^{\circ} 49^{\prime} \mathrm{E}\end{array}$ & VHF radar & J.L.Caccia & LSEET \\
\hline 37 & Bollène & $\mathrm{R} 12$ & $\begin{array}{l}44^{\circ} 17^{\prime} \mathrm{N} / \\
4^{\circ} 45^{\prime} \mathrm{E}\end{array}$ & $\mathrm{O}_{3}$ & M. Zéphoris & DSO \\
\hline 38 & Nîmes & $\mathrm{R} 13$ & $\begin{array}{l}43^{\circ} 46^{\prime} \mathrm{N} / \\
2^{\circ} 5^{\prime} \mathrm{E}\end{array}$ & $\begin{array}{l}\text { Falcon } 20 \\
\text { (Doppler } \\
\text { Lidar WIND) }\end{array}$ & A. Dabas & $\begin{array}{l}\text { CNRM, } \\
\text { LMD, DLR }\end{array}$ \\
\hline 39 & $\begin{array}{l}\text { OHP } \\
\text { Saint Michel }\end{array}$ & R14 & $\begin{array}{l}43^{\circ} 46^{\prime} \mathrm{N} / \\
5^{\circ} 12^{\prime} \mathrm{E}\end{array}$ & $\begin{array}{l}\text { VHF radar, } \\
\mathrm{O}_{3} \text {, radiosonde }\end{array}$ & R. Wilson & SA \\
\hline 40 & Brignoles & R15 & & $\mathrm{O}_{3}, \mathrm{NO} / \mathrm{NO}_{2}$ & D. Robin & Airmaraix \\
\hline 41 & Mérindol & R16 & $\begin{array}{l}43^{\circ} 45^{\prime} \mathrm{N} / \\
5^{\circ} 12^{\prime} \mathrm{E}\end{array}$ & $\mathrm{O}_{3}$, Met station & M. Zéphoris & DSO \\
\hline 42 & Mobile car & $\mathrm{V} 1$ & & $\mathrm{O}_{3}$, Met station & M. Zéphoris & DSO \\
\hline 43 & Mobile car & $\mathrm{V} 2$ & & $\mathrm{O}_{3}$, Met station & M. Zéphoris & DSO \\
\hline 44 & Mobile car (1) & V3 & Marseille & Met station & P. Mestayer & $\mathrm{ECN}$ \\
\hline 45 & $\begin{array}{l}\text { Operational } \\
\text { headquarter }\end{array}$ & & $\begin{array}{l}\text { Aix-en- } \\
\text { Provence }\end{array}$ & Coordination & $\begin{array}{l}\text { B. Cros/ } \\
\text { P. Durand }\end{array}$ & LA, CNRM \\
\hline
\end{tabular}


Appendix B (continued)

\begin{tabular}{|c|c|c|c|c|c|c|}
\hline Station & Site & Code & Location & $\begin{array}{l}\text { Parameters and/ } \\
\text { or instruments }\end{array}$ & $\begin{array}{l}\text { Investigators } \\
\text { in charge }\end{array}$ & $\begin{array}{l}\text { Laboratories } \\
\text { involved }\end{array}$ \\
\hline 45 & $\begin{array}{l}\text { Operational } \\
\text { Headquarter }\end{array}$ & & $\begin{array}{l}\text { Aix-en- } \\
\text { Provence }\end{array}$ & Met forecasting & B. Sol & $\begin{array}{l}\text { DIRSE - } \\
\text { CDM13 }\end{array}$ \\
\hline 46 & $\begin{array}{l}\text { Communication } \\
\text { headquarter }\end{array}$ & & $\begin{array}{l}\text { Aix-en- } \\
\text { Provence }\end{array}$ & Flight coordination & $\begin{array}{l}\text { F. Saïd } \\
\text { C. Noël }\end{array}$ & $\begin{array}{l}\text { LA, CNRM } \\
\text { CNRS/CCR }\end{array}$ \\
\hline
\end{tabular}

M1 and M2: marine sites, E1 to E15: emission sites, I1 to I8: intermediate sites, R1 to R16: remote sites, V1 to V3: mobile sites.

(1) UBL site or instrument;

(2) $\mathrm{GPS} / \mathrm{H}_{2} \mathrm{O}$ site or instrument.

\section{References}

Apel, E.C., Calvert, J.G., Gilpin, T.M., Fehsenfeld, F.C., Parrish, D.D., Lonneman, W.A., 1999. The nonmethane hydrocarbon intercomparison experiment (NOMHICE). J. Geophys. 104 (D21), 26069-26086.

Builtjes, P.J.H., 1992. The LOTOS—Long Term Ozone Simulation-project; summary report. TNO report R92/ 240. Delft, The Netherlands.

Corsmeier, U., Kalthoff, N., Vogel, B., Hammer, M.-U., Fiedler, F., Kottmeier, Ch., Volz-Thomas, A., Konrad, S., Glaser, K., Neininger, B., Lehning, M., Jaeschke, W., Memmesheimer, M., Rappenglück, B., Jacobi, G., 2002. Ozone and PAN formation inside and outside of the Berlin plume-process analysis and numerical process simulation. J. Atmos. Chem. 42, 289-321.

de la Noë, J., Brillet, J., Turati, C., Mégie, G., Godin, S., Pelon, J., Marché, P., Barbe, A., Gibbins, C.J., Dawkins, A.W.J., Matthews, W.A., 1987. Remote and ground-based measurements of ozone profiles during the MAP/ GLOBUS 1983 campaign. Planet. Space Sci. 35 (5).

Ebel, A., Elbern, H., Hass, H., Jacobs, H.J., Memmesheimer, M., Laube, M., Oberreuter, A., Pierkorz, G., 1997. Simulation of chemical transformation and transport or air pollutants with the model system EURAD. In: Ebel, A., Friedrich, R., Rhodes, H. (Eds.), Tropospheric Modelling and Emission Estimation. Springer, Heildelberg, pp. 27-45.

François, S., Boissard, C., Mirabel, P., Noppe, J., Ponche, J.-L., 2000. Methodology of emission inventories in the ESCOMPTE project. Proceedings of the EUROTRAC-2 Symposium (subproject GENEMIS) Transport and Transformation of Pollutants in the Troposphere, Garmisch-Partenkirchen (D), 27-31st March.

Hansel, A., Whisthaler, A., Fall, R., Goldan, P.D., Trainer, M., Ryerson, T.B., Parish, D.D., Huebler, G., Fried, A., Fehsenfeld, F.C., 2002. Airborne in situ observations of VOCs over Houston area during TexAQs 2000. EGS Conference, Nice, France, 22-26 April 2002.

Honoré, C., Vautard, R., 2000. Photochemical regimes in urban atmospheres: the influence of dispersion. Geophys. Res. Lett. 27 (13), 1895-1898.

Jaecker-Voirol, A., Lippardt, M., Martin, B., Quandalle, P., Sallès, J., Carissimo, B., Dupont, E., MussonGenon, L., Riboud, P.M., Aumont, B., Bergametti, G., Bey, I., Toupance, G., 1998. A 3D regional scale photochemical air quality model. Application to a 3 day summertime episode over Paris. Rev. Inst. Fr. Pet. 53 (2), 225-237.

Kleinman, L., Daum, P.H., Imre, D., Lee, Y.-N., Nunnermacker, L.J., Springston, S.R., Weinstein-Lloyd, J., Rudolph, J., 2002. Ozone production rate and hydrocarbon reactivity in 5 urban areas: a cause of high ozone concentration in Houston. Geophys. Res. Lett. 29, 1051-1054.

Kumar, N., Russell, A.G., Tesche, T.W., Mc Nally, D.E., 1994. Evaluation of CALGRIG using two different ozone episodes and comparison to UAM results. Atmos. Environ. 28, 2823-2845.

Lafore, J.P., Stein, J., Asencio, N., Bougeault, N.P., Ducrocq, V., Duron, J., Fischer, C., Hereil, P., Mascart, P., Pinty, J.P., Redelsperger, J.L., Richard, E., Vila-Guerau de Arellano, J., 1998. The Meso-NH atmospheric simulation system: Part I. Adiabatic formulation and control simulations. Ann. Geophys. 16, 90-109. 
Langmann, B., Graf, H., 1994. Another meteorological driver (HIRLAM) for the chemistry transport model (CTM) of the EURAD system: first simulations. In: Borrell, P.M., Borrell, P., Cvitas, T., Seiler, W. (Eds.), Proc. EUROTRAC, Symp. 94. Academic Publishing, The Hague, pp. 830-833.

Martilli, A., Clappier, A., Rotach, M.W., 2000. The urban atmospheric boundary layer: a modelling study. 16th IMACS World Congress 2000, Session on Urban Air Pollution Modelling, Lausanne, Switzerland, 21-25 August.

Menut, L., et al., 2000a. Measurements and modeling of atmospheric pollution over the Paris area: an overview of the ESQUIF project. Ann. Geophys. 18, 1467-1481.

Menut, L., Vautard, R., Beekmann, M., Honoré, C., 2000b. Sensitivity of photochemical pollution using the adjoint of a simplified chemistry-transport model. J. Geophys. Res. 105 (D12), 15379-15402.

Mestayer, P.G., Durand, P., 2002. The UBL/CLU-Escompte experiment: description and first results. Proc. 4th Symposium on Urban Climatology, May 2002, Norfolk, VA, AMS Ed.

Mosssiopoulos, N., 1995. The EUMAC Zooming Model, a tool for local-to-regional air quality studies. Meteorol. Appl. Phys. 57, 115-134.

Neftel, A., 1999. Examples of the importance of trace gas measurements in the Milan ozone plume. Anulusis 27, $325-327$.

Nester, K., 1995. Influence of sea breeze flows on air pollution over the Attica Peninsula. Atmos. Environ. 29, 3655-3670.

Nester, K., Panitz, H.J., Fiedler, F., 1995. Comparison of the DRAIS and EURAD model simulation of air pollution in a mesoscale area. Meteorol. Atmos. Phys. 57, 135-158.

Nester, K., Panitz, H.-J., Wilms-Grabe, W., Zhao, T., 2002. Accuracy of midday ground level ozone concentrations predicted by the KAMM/DRAIS model system. Proceedings of the 6th GLOREAM Workshop, Aveiro.

Peuch, V.H., Amodei, M., Barthet, T., Cathala, M.L., Josse, B., Michou, M., Simon, P., 1999. MOCAGE: Modèle de Chimie A Grande Echelle. AMA 1999, CNRM, Météo-France (Eds.), Toulouse, France

Pielke, R.A., Cotton, W.R., Walko, R.L., Lyons, L.D., Grasso, L.D., Nicholls, M.E., Moran, M.D., Wesley, D.A., Lee, T.J., Coperland, J.H., 1992. A comprehensive meteorological modeling system-RAMS. Meteorol. Atmos. Phys. 49, 69-91.

Pilinis, C., Kassomenos, P., Kallos, G., 1993. Modeling of photochemical pollution in Athens, Greece, application of the RAMS6CALGRID modeling system. Atmos. Environ. 27B, 353-370.

Plass-Dülmer, C., Michl, K., Ruf, R., Berresheim, H., 2002. C2-C8 hydrocarbon measurement and quality control procedures at the Global Atmosphere Watch Observatory Hohenpeissenberg. J. Chromatogr. A. 953, $1-2$.

Ponche, J.L., Zaïdi, N., Fayet, S., Mirabel, Ph., 1998. L'inventaire spatialisé des émissions atmosphériques pour la Région de Strasbourg (Communauté Urbaine de Strasbourg étendue). Pollut. Atmos. 159, 64-72.

Ponche, J.-L., François, S., Noppe, J., 2000a. Cahier des charges préliminaire pour les différentes contributions aux émissions atmosphériques ESCOMPTE. Official Journal of the European Communities on the 18th of February 2000 (2000/s 44-028130), 85 pp.

Ponche, J.-L., Schneider, C., Mirabel, P., 2000b. Methodology and results of the REKLIP atmospheric emission inventory of the upper Rhine valley transborder region. Water Air Soil Pollut. 124, 61-93.

Pont, V., Fontan, J., 2000. Local and regional contributions to photochemical atmospheric pollution in southern France. Atmos. Environ. 34, 5209-5223.

Reitebuch, O., Werner, C., Leike, I., Delville, P., Flamant, P.H., Cress, A., Engelbart, D., 2001. Experimental validation of wind profiling performed by the airborne $10-\mu \mathrm{m}$ heterodyne Doppler lidar WIND. J. Atmos. Ocean. Technol. 18, 1331-1344.

Reitebuch, O., Volkert, H., Werner, C., Dabas, A., Delville, P., Drobinski, P., Flamant, P.H., Richard, E., 2003. Determination of airflow across the Alpine ridge by a combination of airborne Doppler lidar, routine radiosounding and numerical simulation. Qt. J. Royal Meteorol. Soc. 129, 715-727.

Roeckner, E., Arpe, K., Bengtsson, L., Christoph, M., Claussen, M., Dümenil, M., Esch, M., Giorgetta, M., Schlesse, U., Shulzweida, U., 1996. The atmospheric general circulation model ECHAM-4: model description and simulation of present day climate. Report Max-Planck-Institute for Meteorology, Hamburg, Germany.

San José, R., Prieto, J.F., Castellanos, N., Arranz, J.M., 1997. Sensitivity study of dry deposition fluxes in ANA air quality model over Madrid mesoscale area. In: San José, R., Brebbia, C.A. Measurements and Modelling Environmental Pollution. CMP Publications, WIT Press, Southampton, UK. ISBN 185312461 3, 560 pp. 
Sillman, S., Al-Whalil, K.I., Marsik, F.J., Nowacki, P., Samson, P.J., Rodgers, M.O., Garland, M.J., Martinez, J.E., Stoneking, C., Imhoff, R., Lee, J.H., Newmann, L., Weinstein-Lloyd, J., Aneja, V.P., 1995. Photochemistry of ozone formation in Atlanta, GA-models and measurements. Atmos. Environ. 29, 3055-3066.

Slemr, J., Slemr, F., Partridge, R., D’Souza, H., Schmidbauer, N., 2002. Accurate measurements of hydrocarbons in the atmosphere (AMOHA): three European intercomparisons. J. Geophys. Res. 107 (D19), 4409-4421.

Geffroy, S., Frejafon, E., Weidauer, D., Fabian, R., Godet, Y., Nominé, M., Ménard, T., Rairoux, P., Moeller, D., Wolf, J.P., 2002. LIDAR mapping of ozone-episode dynamics in Paris and intercomparison with spot analyzers. Appl. Phys., B 74 (4-5), 453-459.

Tulet, P., Crassier, V., Solmon, F., Guedalia, D., Rosset, R., 2002. Description of the mesoscale non hydrostatic chemistry model and application to a transboundary pollution episode between northern France and southern England. J. Geophys., p. 107.

Vautard, R., Beekmann, M., Roux, J., Gombert, D., 2001. Validation of a hybrid forecasting system for the ozone concentrations over the Paris area. Atmos. Environ. 35, 2449-2461.

Vogel, B., Fiedler, F., Vogel, H., 1995. Influence of topography and biogenic volatile organic compounds emission in the state of Baden-Wuerttemberg on ozone concentrations during episodes of high air temperatures. J. Geophys. Res. 100, 22907-22928.

Volz-Thomas, A., Mihelic, D., Konrad, S., Pätz, H.-W., Houben, N., Platt, U., Perner, D., 2000. Local ozone production rates from photostationary state of $\mathrm{O} 3 / \mathrm{NOx}$ and from peroxy radical measurements in the plume of Berlin during BERLIOZ campaign. EGS Conference, Nice, France, April 2000.

Yamartino, R., 1989. The CALGRID Mesoscale photochemical grid model: I. Model formulation. Atmos. Environ. 26A, 1493-1512.

Ziomas, I.C., 1998. The Mediterranean campaign of photochemical tracers-transport and chemical evolution (MEDCAPHOT-TRACE): an outline. Atmos. Environ. 32, 2045-2053. 